\title{
Testing Price Pressure, Information, Feedback Trading, and Smoothing Effects for Energy Exchange Traded Funds*
}

\author{
Chia-Lin Chang** \\ Department of Applied Economics \\ Department of Finance \\ National Chung Hsing University, Taiwan \\ Yu-Pei Ke \\ Department of Applied Economics \\ National Chung Hsing University, Taiwan
}

Revised: July 2014

* The authors are grateful to Michael McAleer and a referee for very helpful comments and suggestions. For financial support, the authors wish to thank the National Science Council, Taiwan.

**Corresponding author: changchialin@nchu.edu.tw 


\begin{abstract}
This paper examines the relationships between flows and returns for five Exchange Traded Funds (ETF) in the U.S. energy sector. Four alternative hypotheses are tested, including the price pressure hypothesis, information (or price release) hypothesis, feedback trading hypothesis, and smoothing hypothesis. The five ETF are the Energy Select Sector SPDR Fund (XLE), iShares U.S. Energy ETF (IYE), iShares Global Energy ETF (IXC), Vanguard Energy ETF (VDE), and PowerShares Dynamic Energy Exploration \& Production Portfolio (PXE). A Vector Autoregressive (VAR) model is used to analyze the relationships between energy flows and returns. The empirical results show that energy returns and subsequent energy ETF flows have a negative relationship, thereby supporting the smoothing hypothesis. Moreover, the smoothing effect exists for XLE and IYE during the global financial crisis. Regardless of whether the whole sample period or the sub-samples before, during and after the global financial crisis are used, no evidence is found in support of the price pressure hypothesis, information hypothesis, or feedback trading hypothesis.
\end{abstract}

Keywords: Energy Exchange Traded Funds (ETF), Price pressure hypothesis, Information hypothesis, Feedback trading hypothesis, Smoothing hypothesis.

JEL: G14, G15, C32 


\section{Introduction}

Fama (1970) examined the efficient markets hypothesis that plays an important role in the analysis of financial markets. The efficient markets hypothesis states that investors are capable of responding to market information rationally and efficiently, so that stock prices fully reflect the information in the market. Many empirical studies have not able to support the efficient markets hypothesis, so that investors can obtain more than normal profits from trading in securities.

The literature on stock market flows and returns has suggested the following four hypotheses:

(1) The price pressure hypothesis means that the effect of flows on current market returns is negative. When the stock market demand curve is not perfectly elastic, investors in the stock market buy (sell) shares, leading to equity flowing in and out. There is buying (selling) pressure in the market, pushing the stock price up (down), leading to a temporary deviation from the equilibrium price, resulting in positive (negative) market returns. Over time, the presence of buying (selling) pressure in the market slowly vanishes, and stock prices revert to the original equilibrium, so that the market will have negative (positive) returns.

(2) The information (or price release) hypothesis refers to flows in the stock market and current market returns having a positive relationship. A positive correlation between market flows and returns implies that investors have superior private information when trading funds, which means that useful information is present in the market.

(3) The feedback trading hypothesis is defined where market returns and current market flows are positively related. When the market returns in the current period are positive (negative), investors are optimistic (pessimistic) about market prospects, thereby expecting future market returns to continue to rise (decrease). Investors choose to buy 
(sell) securities so that securities flows rise (decrease).

(4) The smoothing hypothesis (see Chang et al. (2013)) suggests that market returns and current securities flows are negatively related. This relationship suggests that investors regard a rise (fall) in security prices as an overreaction in the market, and choose to sell (buy) securities, thereby reducing securities flows.

The global financial crisis caused economic turmoil and led to many changes, with many investors seeking stable, secure, and profitable financial products. Unlike highly risky and volatile stock and futures markets, the Exchange Traded Funds (ETF) management strategy is to invest in a basket of securities or commodities by tracking a particular index performance. As ETF are listed in stock exchanges, investors can be linked to price movements and a specific index of stock investment portfolio (such as S\&P500 or NASDAQ). Not only do ETF have the advantage of diversified investments, they also have flexible features of stock trading, and hence combine the appealing characteristics of stocks and mutual funds.

As oil prices are a key factor influencing the global economy and the international political environment, international crude oil prices appear highly volatile and affect international financial markets. The literature has mainly explored the impact of oil prices on stock market prices (see, for example, Sadorsky, 1999; Ghouri, 2006; Kilian,and Park, 2009; Arouri, 2011; Naifar and Al Dohaiman, 2013; Chang, McAleer and Tansuchat, 2013; Cunado, and de Gracia, 2014), but far less so the relationship between the energy sector's share prices and trading volumes. Based on the earning prospects of energy stocks, and compared with investing in stocks or energy futures markets, energy ETF can more readily spread risk for investors. Consequently, this paper selects five energy ETF to examine the relationships between energy ETF flows and returns, and to test four different hypotheses regarding flows and returns. 
The remainder of the paper is organized as follows. Section 2 provides a review of the literature, Section 3 introduces the empirical model, Section 4 explains the data, Section 5 discusses the empirical results, and Section 6 gives some concluding comments.

\section{Review of the Literature}

Purchasing stocks and (possibly) generating positive returns indicates a positive correlation should arise between flows and returns. If there is a negative correlation between fund flows and current market returns, the price pressure hypothesis is said to occur. Harris and Gurel (1986) find that investors in the U.S. stock market cause share prices to fluctuate. Previous stock flows impact negatively on current returns, thereby leading to the price pressure hypothesis.

Warther (1995) analyzes the relationship among U.S. stock funds, bond funds, and precious metal funds, and their corresponding market returns. The empirical results show that the flows of three fund markets and their respective returns do not have a significant negative relationship. These studies are unable to support the price pressure hypothesis. Jinjarak et al. (2011) examine the relationship between stock fund flows and returns, as well as the relevance of bond fund flows and rewards. They divide international funds into developed countries (namely North America, Europe, the Pacific) and emerging countries (namely, Asia, emerging Europe, Middle East and Latin America) to explore the relationship between fund flows and market returns across different regions. Rakowski and Wang (2009) analyze the relationship between U.S. mutual fund flows and market returns. Oh and Parwada (2007) find that the empirical results are unable to support the price pressure hypothesis for Korean mutual funds.

Ben-Rephael et al. (2011) analyze Israel’s stock mutual funds and discover that fund flows and current market returns have a significant negative correlation, which supports 
the price pressure hypothesis. Ülkü and Weber (2013) analyze the relevance between Korean stock flows and market returns, dividing stocks into three major investment groups, namely domestic individuals, domestic institutions, and foreign investors. The empirical results show that, of the three major investment groups, only the domestic stocks group supports the price pressure hypothesis.

If an investor has private information and an ability to predict returns in the market, the relationship between previous flows and current returns continue to be positive. Given market information, investors will take it into account to predict market returns, so that the relationship between fund flows and market returns will be positive. Rakowski and Wang (2009) analyze U.S. mutual fund flows and market returns, and support the information hypothesis. Ülkü and Weber (2013) use Korean mutual fund flows and market returns, as discussed above, and their empirical results show that foreign investors have superior private information when trading mutual funds, which supports the information hypothesis.

Warther (1995) and Jank (2012) divide fund flows into expected and unexpected flows. Their empirical results show that unexpected fund flows and market returns are positively correlated, but that expected fund flows and returns have no significant relationship. It is implicit that unexpected fund flows may contain information that impacts on market returns, and are positively related. Watson and Wickramanayake (2012) analyze mutual funds data in Australia and find a positive correlation between expected flows and market returns, which supports the information hypothesis.

Returns relative to flows for the same period show positive correlations, known as the intraday feedback trade. If investors are optimistic (pessimistic) about market prospects, hold that market returns will continue to increase (decrease) in the future, and decide to buy (sell) the fund, causing the fund flow to increase (decrease), the relationship 
will be positive. When fund returns and current market flows are positively correlated, this is called the feedback trading hypothesis. Ülkü and Weber (2013) separate Korean stocks into domestic individuals, domestic institutions, and foreign investors. Their empirical results show that the effects of domestic individual and foreign investor market returns on stock flows show a significant positive correlation, denoting support for the intraday feedback trading hypothesis.

Jinjarak et al. (2011) find that emerging Europe, the Middle East and Latin America's fund returns are positively related to current fund flows, thereby supporting the feedback trading hypothesis. Warther (1995) and Boyer and Zheng (2009) find there is not a positive correlation between market returns and current fund flows for U.S. funds, so that their empirical results do not support the feedback trading hypothesis.

Unlike the previous literature that concentrates on mutual funds, Kalaycioglu (2004) argue that ETF are often seen as arbitrage tools by investors. Thus, when markets are in a bullish phase, market returns will rise, as will the demand for investment in the market, so that investors will invest in the stock market and sell ETF. Therefore, lagged market returns and ETF fund flows will be negatively correlated, which is the smoothing hypothesis. Oh and Parwada (2007) and Rakowski and Wang (2009) examine mutual funds in Korea, and find empirical support for the smoothing hypothesis.

In addition to analyzing the relationship between fund flows and returns, Jinjarak et al. (2011) argue that, when the stock market experiences a negative impact, it will cause investors to reconfigure their portfolios. Previous stock market returns can affect current bond fund flows, and past bond fund flows can affect current stock market returns. Boyer and Zheng (2009) categorize the stock market into six investment groups, namely mutual funds, households, foreign investors, insurance companies, pension funds, and closedend funds. They find that fund flows from the different investment groups will be 
mutually influenced, such that mutual fund flows lead to an increase in current insurance company fund flows.

Jank (2012) analyzes the factors that affect fund flows, and chooses an indicator of overall substantial economic activity, such as the dividend-price ratio, relative Treasury bill interest rate, and consumer wealth ratio, as predictive variables. These variables are forward looking, reflecting substantive economic activity. Quarterly data on U.S. stock fund flows are used to analyze the effect of the predictive variables and market returns on fund flows. The empirical result show that the three macroeconomic variables have a remarkable impact on fund flows. Compared with market returns, market information (that is, the predictive variables) is argued by Jank (2012) to be more suitable for explaining mutual fund flows. Jank (2012) finds that mutual fund flows significantly affect the four indicators of economic activity, namely real GDP, industrial production index, consumer price index, and labor income, but finds no other significant impact.

Rakowski and Wang (2009) use Korean mutual fund data and find that investors with higher marketing expenses have lower search costs, so that it is easier to obtain information. An increase in marketing costs affects fund flows positively, but investors may be less willing to bear the costs required for the fund's redemption, which may result in reduced fund flows.

\section{VAR Model}

The literature on fund flows and market returns typically uses the Vector Autoregressive (VAR) model to analyze the relationships among the endogenous and exogenous variables. Sims (1980) argues that identification of the endogenous and exogenous variables can be difficult, and has proposed the VAR model. The paper explores the relationships between energy ETF market fund flows and returns using the 
VAR model, and examines four hypotheses for the energy ETF market.

The following is the VAR model with $p$ lags to be estimated:

$\left[\begin{array}{c}\text { Return }_{t} \\ \text { Flow }_{t}\end{array}\right]=\left[\begin{array}{c}\alpha_{1} \\ \alpha_{2}\end{array}\right]+\sum_{i=1}^{p}\left[\begin{array}{ll}\beta_{11, i} & \beta_{12, i} \\ \beta_{21, i} & \beta_{22, i}\end{array}\right]\left[\begin{array}{c}\text { Return }_{t-i} \\ \text { Flow }_{t-i}\end{array}\right]+\left[\begin{array}{c}\varepsilon_{1 t} \\ \varepsilon_{2 t}\end{array}\right]$

where Return $_{\mathrm{t}}=\mathrm{ETF}$ returns at time $\mathrm{t}$,

Flow $_{\mathrm{t}}=$ ETF flow at time $\mathrm{t}$,

$\varepsilon_{1 \mathrm{t}}$ and $\varepsilon_{2 \mathrm{t}}$ are white noise error terms.

The four hypotheses to be tested are given as follows:

(1) $\beta_{12}<0$ : price pressure hypothesis;

(2) $\beta_{12}>0$ : information (or price release) hypothesis;

(3) $\beta_{21}>0$ : feedback trading hypothesis;

(4) $\beta_{21}<0$ : smoothing hypothesis.

In equation (1), $\beta_{12}$ denotes the effect of energy ETF flows on returns, with $\beta_{12}<$ 0 indicating the price pressure hypothesis, and $\beta_{12}>0$ indicating the information hypothesis. The parameter $\beta_{21}$ represents the impact of energy ETF returns on flows, with $\beta_{21}>0$ indicating the feedback trading hypothesis, and $\beta_{21}<0$ indicating the smoothing hypothesis (see Chang et al. (2013)). The parameters $\beta_{11}$ and $\beta_{22}$ are the autoregressive coefficients for energy returns and fund flows, respectively.

In order to support the information hypothesis, the paper also decomposes ETF fund flows into expected and unexpected flows. When unexpected fund flows contain private information, which may have a positive impact on energy returns, with unexpected energy 
fund flows and current energy returns having a positive correlation, this supports the information hypothesis. Based on the estimates of Warther (1995) and Jank (2012) for unexpected flows, we model fund flows as an AR(1) process, as follows:

Flow $_{t}=c+$ Flow $_{t-1}+\varepsilon_{t}$

Using equation (2), the estimated (or expected) energy fund flows are given as:

$\operatorname{ExpFlow}_{t}=$ Flow $_{t}$

so that the unexpected energy fund flows can be obtained as follows:

UFlow $_{t}=$ Flow $_{t}-$ Flow $_{t}$.

The VAR model of unexpected energy fund flows and energy returns is given as:

$\left[\begin{array}{l}\text { Return }_{t} \\ \text { UFlow }_{t}\end{array}\right]=\left[\begin{array}{l}\alpha_{1} \\ \alpha_{2}\end{array}\right]+\sum_{i=1}^{p}\left[\begin{array}{ll}\beta_{11, i} & \beta_{12, i} \\ \beta_{21, i} & \beta_{22, i}\end{array}\right]\left[\begin{array}{l}\operatorname{Return}_{t-i} \\ \text { UFlow }_{t-i}\end{array}\right]+\left[\begin{array}{l}\varepsilon_{1 t} \\ \varepsilon_{2 t}\end{array}\right]$

where UFlow $_{\mathrm{t}}$ denotes the unexpected energy ETF flows.

In equation (5), the coefficient $\beta_{12}$ denotes the effect of unexpected energy ETF flows on energy returns, with $\beta_{12}>0$ indicating the information hypothesis. The parameter $\beta_{21}$ represents the impact of energy ETF returns on unexpected flows, and $\beta_{11}$ and $\beta_{22}$ represent the autocorrelation coefficients of the energy ETF returns and unexpected energy flows, respectively. 


\section{Data}

This paper uses five listed energy ETF in the U.S. Securities Exchange, namely Energy Select Sector SPDR Fund (XLE), iShares U.S. Energy ETF (IYE), iShares Global Energy ETF (IXE), Vanguard Energy ETF (VDE), and Powershares Dynamic Energy Exploration and Production Portfolio (PXE), which are shown in Table 2.

Energy Select Sector SPDR Fund (XLE) is the biggest energy ETF in the USA, and is issued by the State Street Global Advisors Funds Management, Inc. XLE listed on the New York Stock Exchange on 16 December 1998, and is intended to track the S\&P 500 Composite Index. The Energy Select Sector Index includes oil, gas and consumable fuels, and energy equipment and services. The top 3 holdings for XLE are Exxon Mobil Corporation (14.85\%), Chevron Corporation (12.74\%), and Schlumberger Limited (7.98\%).

iShares US Energy ETF (IYE) is issued by iShares, which listed on the New York Stock Exchange on 12 June 2000, and is intended to track the Dow Jones U.S. Oil \& Gas Index. The overall size and volume are much smaller than XLE, but is still in the top three ETF for the energy sector in the USA. The underlying index gauges the performance of the oil and gas sector of the US equities markets, and includes oil and gas producers, oil equipment companies, and oil and gas services and distribution firms. The top 3 holdings for IYE are Exxon Mobil Corporation (20.94\%), Chevron Corporation (11.91\%), and Schlumberger Limited (7.29\%).

iShares US Energy ETF (IXE) is also issued by iShares, which listed on the New York Stock Exchange on 12 November 2001, and is intended to track the S\&P Global 1200 Index. The underlying index is a subset of the S\&P Global 1200 Index, and includes oil services and equipment companies, refineries and storage, E\&P firms, and pipelines. 
The top 3 holdings for IXE are Exxon Mobil Corporation (13.02\%), Chevron Corporation (7.41\%), Total SA(5.07\%), and BP Public Limited Company (4.92\%).

Vanguard Energy ETF (VDE) is issued by Vanguard Equity Investment Group, listed on the New York Stock Exchange on 23 September 2004, and is intended to track the Morgan Stanley Capital International (MSCI) US Investable Market Energy Index. VDE employs a passive management or indexing investment approach that is designed to track the performance of the Morgan Stanley Capital International (MSCI) US Investable Market Energy Index (the Index), an index of stocks of large, medium and small U.S. companies in the energy sector, as classified under the Global Industry Classification Standard (GICS). This GICS sector comprises companies whose businesses are dominated by activities such as the construction or provision of oil rigs, drilling equipment, and other energy-related service and equipment (such as seismic data collection), or companies engaged in the exploration, production, marketing, refining, and/or transportation of oil and gas products. The top 3 holdings for VDE are Exxon Mobil Corporation (20.9\%), Chevron Corporation (11.3\%), and Schlumberger Limited $(6.5 \%)$

Powershares Dynamic Energy Exploration and Production Portfolio (PXE) is issued by INVESCO Asset Management Limited, listed on the New York Stock Exchange on 26 October 2005, and is intended to track the Dynamic Energy Exploration \& Production IntellidexSM Index. PXE is based on the Dynamic Energy Exploration \& Production IntellidexSM Index. The underlying Intellidex Index is comprised of 30 U.S. stocks involved in the exploration and production of natural resources used to produce energy. These companies are engaged principally in the exploration, extraction and production of crude oil and natural gas from land-based or offshore wells. The top 3 Holdings for PXE are EOG Resources Inc. (5.27\%), Marathon Oil Corporation (5.26\%), and Chesapeake 
Energy Corporation (5.20\%).

The data were downloaded from the Datastream database, with daily data of the five energy ETF closing prices and trading volumes. In the case of a national holiday, the value of the previous day is used. As the issuance date of each energy ETF is different, for consistency the sample is taken from 1 November 2005 to 3 January 2014, with 2,134 sample observations.

Energy ETF fund flows $\left(\right.$ Flow $_{\mathrm{t}}$ ) use energy ETF daily trading volumes as a flow variable, while ETF fund returns $\left(\right.$ Return $\left._{\mathrm{t}}\right)$ are calculated as the log difference of closing prices, $\left(\log \mathrm{P}_{\mathrm{t}}-\log \mathrm{P}_{\mathrm{t}-1}\right)$. Descriptive statistics are given in Table 2 .

The five individual Energy ETF returns from early August 2008 to late March 2009 are in a stable range, as shown in Figure 1. The volatility range of XLE is between 4\% and $-4 \%$. Figure 2 shows the volatility range of IYE is between $3 \%$ and $-3 \%$, while the ranges of IXC, VDE, PXE in Figures 3, 4 and 5, respectively, are between 5\% and -5\%. Therefore, the largest energy ETF returns volatility range is for IXC, VDE and PXE, while the smallest volatility range is IYE, but there does not seem to be any differences between the series.

The five energy ETF flows for the full sample period are given in Figures 6-10. These figures are generally consistent with typical financial returns series, with periods of low volatility interspersed with periods of high volatility. However, the number of extreme observations, though not outliers, seem to be more prevalent than those in typical financial returns series.

The global financial crisis (GFC) occurred from August 2008 through to March 2009, as shown in the circled portion of Figures. 1-5. Each energy ETF returns showed significant fluctuations. The XLE volatility was between $16 \%$ and $-16 \%$, that of IYE was between $23 \%$ and $-23 \%$, for IXC was between $15 \%$ and $-15 \%$, and for both VDE and 
PXE were between $20 \%$ and $-20 \%$. Of the five energy ETF samples, the maximum fluctuation was for IYE, while the IXC volatility was the minimum, with a difference of 8\%. Comparing the differences in the returns volatility before, during and after the GFC, XLE was $12 \%$, IYE was $18 \%$, IXC was $10 \%$, and both VDE and PXE were 15\%. In May 2011 the five energy ETF returns appeared to have smaller fluctuations, with the overall volatility not as dramatic as during the GFC.

The empirical analysis decomposes the full sample period into three sub-periods: (i) before the GFC, from 1 November 2005 to 31 July 2008; (ii) during the GFC, from 1 August 2008 to 31 March 2009; and (iii) after the GFC, from 1 April 2009 to 3 January 2014. In terms of the number of observations in these sub-samples, the total number of observations is 713 before the GFC, 173 during the GFC, and 1243 after the GFC.

\section{Empirical Results}

\subsection{Dynamic Effects of Energy ETF Flows and Returns}

The use of VAR models will enable an understanding of the dynamic relationships between energy ETF fund flows and returns. The ADF tests of unit roots are shown in Table 3. The unit root tests for the Energy ETF fund flows and returns reject the null hypothesis of a unit root, which means that energy ETF fund flows and returns are stationary (for example, see Dickey and Fuller, 1979; Said and Dickey, 1984; Granger and Newbold, 1974), so that the VAR model can be conducted on the flows and returns. Table 4 reports the empirical results of five energy ETF for the full sample period. Tables 5-9 report the empirical results for XLE, IYE, IXC, VDE, PXE before, during and after the GFC.

From the results in Table 4, for the full sample period, the five energy ETF current and lagged flows generally have positive correlations up to five lags, but the current and 
lagged returns have a significant negative correlation.

In the five energy ETF markets, the largest trading volume and total assets are the Energy Select Sector SPDR Fund (XLE). XLE energy returns lagged one and two periods have significant negative effects on current energy fund flows. The coefficients are -0.716 and -0.220 , respectively, so that, for the full sample period, when energy returns increase by $1 \%$, ETF fund flows will have a reverse outflow of 0.936 (thousand shares), which supports the smoothing hypothesis. The longer is the lag period, the smaller is the significant impact on energy fund flows, sot that the smoothing effects will disappear gradually. The trading volume of iShares US Energy ETF (IYE) ranked second, and returns have significant negative relationships lagged one and two periods with current energy fund flows. The coefficients are -0.018 and -0.014 , respectively, so that for the full sample period, when energy returns increase by 1\%, ETF fund flows will have a reverse outflow of 0.032 (thousand shares).

The trading volume of iShares Global Energy ETF (IXC) was ranked third. Only with one lag is there a significant negative correlation of -0.01 , which means that when energy returns increase by 1\%, ETF fund flows have a reverse outflow of 0.01 (thousands shares). The smoothing hypothesis is supported, and the longer is the lag, the smaller is the significant impact on energy fund flows, so that the smoothing effect will disappear gradually.

The Vanguard Energy ETF (VDE) trading volume was ranked fourth, but with the highest market value and total assets ranked second. Previous energy returns and current energy fund flows with one lag have a significant negative correlation. The coefficient is -0.003 , so that when the energy returns increase by $1 \%$, ETF fund flows have a reverse outflow of 0.003 (thousand shares). In supporting the smoothing hypothesis, the longer is the time lag, the smaller is the impact on energy fund flows. 
The trading volume of Powershares Dynamic Energy Exploration and Production Portfolio (PXE) is the last of the five ETF. Energy returns lagged one and two periods and current energy fund flows have significant negative relationships, with coefficients of -0.001 and -0.001 , respectively, so that for the full sample, when energy returns increase by 1\%, ETF fund flows will have a reverse outflow of 0.002 (thousand shares), thereby supporting the smoothing hypothesis.

Overall, the price pressure hypothesis is not supported in the energy ETF markets. The ETF are passively managed funds, so that the purpose of the energy ETF is generally the same as the trend of the benchmark index. Hence, investors seem to pay greater attention to changes in energy returns, and are not concerned about changes in energy flows.

Table 5 reports the empirical results for XLE before, during and after the GFC. XLE energy returns lagged one period impacts current energy fund flows. Before, during and after the GFC, there are significant negative correlations. The coefficients of -0.921 , -0.590 and -0.721 , respectively, support the smoothing hypothesis before, during and after the GFC, but the effect of smoothing during the GFC is smaller than before and after the GFC.

Table 6 reports the empirical results for IYE before, during and after the GFC. Only during the GFC do IYE energy returns lagged one and two periods and current energy ETF flows have significant negative correlations, with coefficients of -0.025 and -0.025 , respectively. The smoothing hypothesis is supported during the GFC, with the effects before and after the GFC not being very clear.

Table 7 reports the empirical results for IXC before, during and after the GFC. Before the GFC, the IXC energy returns lagged one period and current energy ETF flows have a 
significant negative correlation, with a coefficient of -0.032 . Therefore, the smoothing effect for IXC is significant before the GFC, but it is not clear during and after the GFC.

Table 8 reports the empirical results for VDE before, during and after the GFC. Only before the GFC do VDE energy returns lagged one and two periods and current energy ETF flows have significantly negative correlations, with coefficients of -0.004 and -0.004 , respectively. Thus, the effect of the smoothing hypothesis is present only before the GFC, with the effect during and after the GFC being unclear.

Table 9 reports the empirical results for PXE before, during and after the GFC. PXE energy returns lagged one period impacts on current energy fund flows, and has significant negative correlations before and after the GFC, with coefficients of -0.003 and -0.002 , respectively.

In order to examine the robustness of the empirical results, the full sample is divided into sub-samples before, during, and after the GFC. Apart from XLE and IYE, which still have significant effects of the smoothing hypothesis during the GFC, for IXC, VDE, and PXE, significant smoothing effects are found only before and after the GFC.

Overall, regardless of the sub-periods before, during and after the GFC, the correlations of energy ETF flows and returns are negative but not significant. The results in Tables 5-9 do not support the price pressure hypothesis in the energy ETF markets, but do support the smoothing hypothesis. The smoothing effects of most of the energy ETF before and after the GFC is stronger than during the GFC. As energy ETF relate to passively managed funds, for which investment risk is smaller compared with actively managed funds or other financial instruments, especially during the GFC, investors are more inclined toward passively managed funds in energy ETF markets.

In summary, the five energy ETF's energy returns and flows have negative correlations for up to two lags, thereby supporting the smoothness hypothesis. 
Energy returns lagged one or two periods and corresponding current energy fund flows have significant negative correlations, indicating an increase in energy prices leads to positive energy returns. Investors may believe that the price of energy ETF overreacts to market information under the smoothing hypothesis, investors decide to sell energy Fund ETF in the current period, with the empirical results supporting the finding in Kalaycioglu (2004) for mutual funds. Regardless of the empirical results for the full sample or before and after the GFC, the greater is the volume of energy ETF, the clearer is the overall smoothing effect.

Moreover, regardless of the empirical analysis for the full sample or sub-samples before, during and after the GFC, the price pressure hypothesis is not supported in the five energy ETF markets. Thus, energy ETF flows have no significant impact on current energy ETF returns, so there may be other factors that affect the price of energy ETF. In the following section, we use unexpected energy fund flows to examine if they can significantly affect energy returns in testing the information hypothesis.

\subsection{Energy ETF Unexpected Flows and Returns}

The previous section found there was no significant relationship between total energy fund flows and energy returns. Warther (1995) and Jank (2012) categorized fund flows into expected and unexpected flows to examine the correlations with market returns, and found significant relationships between market returns and unexpected flows. Using the VAR model, this paper explores the relationship between energy ETF returns and unexpected energy flows, with the empirical results given in Table 10.

Overall, previous unexpected energy ETF flows have no positive impact on current energy ETF returns. The five energy ETF do not support the information hypothesis so that, regardless of the total or unexpected fund flows, previous fund flows do not impact 
significantly on current energy returns. This outcome is not consistent with the results of Warther (1995) and Jank (2012), who obtained positive correlations between unexpected fund flows and market returns. One possible reason is that the information on the stocks comprising the ETF portfolio and the constituent stocks of the benchmark index are relatively transparent, so there is little private information that affects energy prices.

Regardless of the use of total or unexpected energy fund flows, a negative correlation with energy returns lagged one period is found, thereby supporting the smoothing hypothesis in the energy ETF markets. Total energy ETF fund flows or unexpected energy fund flows and current energy returns do not have a significant relationship, so that the price pressure and information hypotheses are not supported in energy ETF markets. However, the use of unexpected flows from the VAR model renders the empirical results more robust.

\section{Conclusion}

This paper explored the relationships between energy market ETF fund flows and energy returns in five energy ETF, and tested four hypotheses, namely the price pressure hypothesis, information hypothesis, feedback trading hypothesis, and smoothing hypothesis. The five energy ETF were Energy Select Sector SPDR Fund (XLE), iShares U.S. Energy ETF (IYE), iShares Global Energy ETF (IXE), Vanguard Energy ETF (VDE), and Powershares Dynamic Energy Exploration and Production Portfolio (PXE).

The VAR model was used to analyze the relationships between energy flows and returns. In order to facilitate the comparison, the sample periods of each Energy ETF were from 1 November 2005 to 3 January 2014, with each energy ETF having 2,134 observations. The empirical results found that energy returns and corresponding energy ETF flows generally had negative correlations, thereby supporting the smoothing 
hypothesis. The smoothing effect of energy returns lagged one day was most significant. The greater was the lag length, the less clear was the smoothing effect, with the smoothing effect disappearing gradually over time.

The smoothing effect of XLE was the greatest. When XLE returns increased by 1\%, flows would have a reverse outflow of 0.936 (thousand shares). The smoothing effect of PXE was the lowest so that, when PXE returns increased by $1 \%$, flows would have an outflow of 0.001 (thousand shares). On the whole, the greater (lesser) was the volume of energy ETF, the greater (lesser) was the effect of the smoothing hypothesis.

The empirical analysis separated the samples into three sub-periods, namely before, during and after the GFC, to examine if the smoothing effect remained in XLE and IYE with a greater effect during the GFC, and for IXC, VDE and PXE, with a smaller effect before or after the GFC. Overall, regardless of whether the full sample or the sub-samples before, during and after the GFC were used, there was no evidence of the price pressure hypothesis, feedback trading hypothesis, or the information hypothesis.

In examining the robustness of the tests of the information hypothesis, the empirical analysis evaluated the effects of lagged unexpected energy ETF flows on current returns. The empirical results did not support the existence of the information hypothesis in energy ETF markets.

Whether for the full sample or the sub-samples before, during and after the GFC, the effect of energy ETF flows on returns was not statistically significant, so that the price pressure hypothesis was not supported, but the smoothing hypothesis was supported. As energy ETF relate to passively managed funds for which the investment risk is small, especially during the GFC, conservative investors would be more inclined toward energy ETF markets to reduce investment risk. In other words, during stock market downturns, investors invest in ETF, which is consistent with general market movements. Overall, 
energy ETF are more defensive relative to investing in stock market shares as a way of managing risk. 


\section{Reference}

Arouri, M.E.H. (2011), "Does Crude Oil Move Stock Markets in Europe? A Sector Investigation,” Economic Modelling, 28, 1716-1725.

Ben-Rephael, A., S. Kandel, and A. Wohl (2011), “The Price Pressure of Aggregate Mutual Fund Flows”, Journal of Financial and Quantitative Analysis, 46, 585-603.

Boyer, B. and L. Zheng (2009), “Investor Flows and Stock Market Returns”, Journal of Empirical Finance, 16, 87-100.

BlackRock, Inc. (2014). “iShares Global Energy ETF Fact Sheet”. Retrieved from http://www.ishares.com/us/literature/fact-sheet/ixc-ishares-global-energy-etffund-fact-sheet-en-us.pdf, accessed 25/07/2014.

BlackRock, Inc. (2014). “iShares U.S Energy ETF Fact Sheet”. Retrieved from http://www.ishares.com/us/literature/fact-sheet/iye-ishares-u-s-energy-etf-fundfact-sheet-en-us.pdf, accessed 25/07/2014.

Chang, C.-L., M. McAleer and R. Tansuchat (2013), “Conditional Correlations and Volatility Spillovers between Crude Oil and Stock Index Returns”, North American Journal of Economics and Finance, 25, 116-138.

Chang, C.-L., B. de Bruijn, P.H. Franses, and M. McAleer (2013), “Analyzing Fixedevent Forecast Revisions”, International Journal of Forecasting, 29, 622-627.

Cunado, J. and F.P. de Gracia (2014), “Oil Price Shocks and Stock Market Returns: Evidence for Some European Countries”, Energy Economics, 42, 365-377.

Dickey, D.A. and W.A. Fuller (1979), "Distribution of the Estimators for Autoregressive Time Series with a Unit Root,” Journal of the American Statistical Association, 76, 427-431.

Fama, E.F. (1970), “Efficient Capital Markets: A Review of Theory and Empirical Work”, The Journal of Finance, 25, 383-417.

Ghouri, S.S. (2006), “Assessment of the relationship between oil prices and US oil stocks”, Energy Policy, 34(17), 3327-3333.

Granger, C.W.J. and P. Newbold (1974), “Spurious Regressions in Econometrics,” 
Journal of Econometrics, 2, 111-120.

Harris, L. and E. Gurel (1986), "Price and Volume Effects Associated with Changes in the S\&P 500 List: New Evidence for the Existence of Price Pressures”, The Journal of Finance, 41, 815-829.

IEA (2012), “World Energy Outlook,” International Energy Agency, Paris. Retrieved from (http://www.worldenergyoutlook.org/publications/weo-2013/, accessed 25/04/2014).

Invesco Ltd. (2014). “PowerShares Dynamic Energy Exploration \& Production Portfolio

Fact Sheet”. Retrieved from (https://www.invesco.com/static/us/financialprofessional/contentdetail?contentId=535407c649400410VgnVCM10000046f1bf0a

$\underline{\text { RCRD, }}$, accessed 10/04/2014)

Jank, S. (2012), “Mutual Fund Flows, Expected Returns, and the Real Economy”, Journal of Banking and Finance, 36, 3060-3070.

Jinjarak, Y., J. Wongswan, and H. Zheng (2011), “International Fund Investment and Local Market Returns”, Journal of Banking and Finance, 35, 572-587.

Kalaycioglu, S. (2004), “Exchange Traded Fund Flows,” SSRN Working Paper Series, http://papers.ssrn.com/sol3/papers.cfm?abstract_id=881108, accessed 25/04/2014).

Kilian, L. and C. Park (2009), “The Impact of Oil Price Shocks on the U.S. Stock Market,” International Economic Review, 50(4), 1267-1287.

Naifar, N. and M.S. Al Dohaiman (2013), "Nonlinear Analysis among Crude Oil Prices, Stock Markets' Return and Macroeconomic Variables”, International Review of Economics \& Finance, 27, 416-431.

Oh, N.Y. and J.T. Parwada (2007), "Relations between Mutual Fund Flows and Stock Market Returns in Korea”, Journal of International Financial Market, Institutions and Money, 17, 140-151.

Rakowski, D. and X. Wang (2009), “The Dynamics of Short-term Mutual Fund Flows and Returns: A Time-series and Cross-sectional Investigation”, Journal of Banking 
and Finance, 33, 2102-2109.

Sadorsky, P. (1999), “Oil price shocks and stock market activity”, Energy Economics, 21, 449-469.

Said, S.E. and D.A. Dickey (1984), “Testing for Unit Roots in Autoregressive Moving Average Models of Unknow Order”, Biometrika, 71, 599-607.

Sims, C. (1980), “Macroeconomics and Reality”, Econometrics, 48, 1-48.

SSgA Funds Management, Inc. (2014), “Energy Select Sector SPDR Fund Fact Sheet”. Retrieved from https://www.spdrs.com/library-content/public/ETFXLE_20140630_114414.pdf, accessed 25/04/2014.

The Vanguard Group, Inc. (2014). "Vanguard Energy ETF Fact Sheet”. Retrieved from https://institutional.vanguard.com/iippdf/pdfs/FS951R.pdf, accessed 25/07/2014.

Toda, H.Y. and T. Yamamoto (1995), “Statistical Inference in Vector Autoregressions with Possibly Intergrated Processes”, Journal of Econometrics, 66, 225-250

Ülkü, N. and E. Weber (2013), “Identifying the Interaction between Stock Market Returns and Trading Flows of Investor Types: Looking into the Day Using Daily Data”, Journal of Banking and Finance, 37, 2733-2749.

Watson, J. and J. Wickramanayake (2012), “The Relationship between Aggregate Managed Fund Flows and Share Market Returns in Australia”, Journal of International Financial Markets, Institutions and Money, 22, 451-472.

Warther, V.A. (1995), “Aggregate mutual fund flows and security returns”, Journal of Financial Economics, 39, 209-235. 
Table 1. Energy ETF

\begin{tabular}{|c|c|c|c|}
\hline $\begin{array}{c}\text { Ticker } \\
\text { Symbol }\end{array}$ & ETF Name & $\begin{array}{c}\text { Total Assets } \\
\text { (Thousand } \\
\text { dollars) }\end{array}$ & $\begin{array}{c}\text { Average } \\
\text { Volume } \\
\text { (Shares) }\end{array}$ \\
\hline XLE & Energy Select Sector SPDR Fund & $12,100,662$ & $8,690,942$ \\
\hline IYE & iShares U.S. Energy ETF & $2,183,344$ & 638,356 \\
\hline IXC & iShares Global Energy ETF & $1,111,734$ & 235,089 \\
\hline VDE & Vanguard Energy ETF & $3,389,387$ & 158,997 \\
\hline PXE & Powershares Dynamic Energy & 145,314 & 44,777 \\
\hline
\end{tabular}

Date source: ETF Database, http://etfdb.com/, accessed 10/07/2014.

Table 2. Summary Statistics (2005/11/01 - 2014/01/03)

\begin{tabular}{c|cccc}
\hline Returns (unit: \%) & Mean & Std. Dev. & Maximum & Minimum \\
\hline XLE_Return & 0.0268 & 1.9929 & 15.2504 & -15.5997 \\
IYE_Return & 0.0272 & 1.9537 & 21.8133 & -20.9865 \\
IXC_Return & 0.0151 & 1.8376 & 14.3384 & -14.0998 \\
VDE_Return & 0.0263 & 1.9719 & 15.7834 & -17.7223 \\
PXE_Return & 0.0343 & 2.2515 & 17.1624 & -18.7646 \\
\hline Flows (unit:1000 shares) & Mean & Std. Dev. & Maximum & Minimum \\
\hline XLE_FLOW & 20.87968 & 11.42172 & 93.38430 & 2.79530 \\
IYE_FLOW & 0.57478 & 0.78647 & 8.26010 & 0.04760 \\
IXC_FLOW & 0.19521 & 0.25189 & 3.32820 & 0.01320 \\
VDE_FLOW & 0.13308 & 0.11887 & 1.08280 & 0.00620 \\
PXE_FLOW & 0.05350 & 0.06256 & 0.54940 & 0.00030 \\
\hline
\end{tabular}


Table 3. Unit root tests

\begin{tabular}{ccccc}
\hline Variables & ADF & $\mathrm{PP}$ & $\mathrm{ADF}$ & $\mathrm{PP}$ \\
& $\mathrm{Z}=\{1\}$ & $\mathrm{Z}=\{1\}$ & $\mathrm{Z}=\{1, \mathrm{t}\}$ & $\mathrm{Z}=\{1, \mathrm{t}\}$ \\
\hline XLE_Return & $-37.336^{*}$ & $-51.773^{*}$ & $-37.328^{*}$ & $-51.760^{*}$ \\
IYE_Return & $-27.616^{*}$ & $-53.842^{*}$ & $-27.610^{*}$ & $-53.828^{*}$ \\
IXC_Return & $-36.371^{*}$ & $-49.901^{*}$ & $-36.363^{*}$ & $-49.888^{*}$ \\
VDE_Return & $-36.870^{*}$ & $-51.288^{*}$ & $-36.861^{*}$ & $-51.275^{*}$ \\
PXE_Return & $-48.030^{*}$ & $-48.430^{*}$ & $-48.022^{*}$ & $-48.424^{*}$ \\
\hline XLE_Flow & $-5.568^{*}$ & $-22.044^{*}$ & $-6.481^{*}$ & $-25.051^{*}$ \\
IYE_Flow & $-4.784^{*}$ & $-25.478^{*}$ & $-4.920^{*}$ & $-26.036^{*}$ \\
IXC_Flow & $-22.339^{*}$ & $-42.588^{*}$ & $-22.346^{*}$ & $-42.574^{*}$ \\
VDE_Flow & $-6.564^{*}$ & $-24.136^{*}$ & $-6.745^{*}$ & $-24.829^{*}$ \\
PXE_Flow & $-5.777^{*}$ & $-46.092^{*}$ & $-7.167^{*}$ & $-44.952^{*}$ \\
\hline
\end{tabular}

Notes: The critical values for the ADF test are $-3.433,-2.863$ and -2.567 at the $1 \%, 5 \%$ and $10 \%$ significance levels when $\mathrm{Z}=\{1\}$, and $-3.962,-3.412$ and -3.128 at the $1 \%, 5 \%$ and $10 \%$ significance levels when $\mathrm{Z}=\{1, \mathrm{t}\}$.

The critical values for the PP test are $-3.433,-2.863$ and -2.567 at the $1 \%, 5 \%$ and $10 \%$ significance levels when $\mathrm{Z}=\{1\}$, and $-3.962,-3.412$ and -3.128 at the $1 \%, 5 \%$ and $10 \%$ significance levels when $\mathrm{Z}=\{1, \mathrm{t}\}$.

An asterisk $(*)$ denotes the null hypothesis of a unit root is rejected at the $1 \%$ significance level. 
Table 4. VAR for Full Sample (2005/11/01 - 2014/01/03)

\begin{tabular}{|c|c|c|c|c|c|c|c|c|c|c|}
\hline & \multicolumn{2}{|c|}{ XLE } & \multicolumn{2}{|c|}{ IYE } & \multicolumn{2}{|c|}{ IXC } & \multicolumn{2}{|c|}{ VDE } & \multicolumn{2}{|c|}{ PXE } \\
\hline & Flow & Return & Flow & Return & Flow & Return & Flow & Return & Flow & Return \\
\hline $\mathrm{C}$ & $\begin{array}{l}2.481^{* *} \\
(7.447)\end{array}$ & $\begin{array}{c}0.186 \\
(1.826)\end{array}$ & $\begin{array}{l}0.073^{* *} \\
(5.188)\end{array}$ & $\begin{array}{c}0.078 \\
(1.422)\end{array}$ & $\begin{array}{l}0.139 * * \\
(14.678)\end{array}$ & $\begin{array}{c}0.021 \\
(0.305)\end{array}$ & $\begin{array}{l}0.017^{* *} \\
(6.565)\end{array}$ & $\begin{array}{c}0.082 \\
(1.176)\end{array}$ & $\begin{array}{l}0.017^{* *} \\
(8.914)\end{array}$ & $\begin{array}{c}0.149 \\
(1.920)\end{array}$ \\
\hline Flow(-1) & $\begin{array}{l}0.440^{* *} \\
(19.816)\end{array}$ & $\begin{array}{c}-0.012 \\
(-1.792)\end{array}$ & $\begin{array}{l}0.465^{* *} \\
(21.415)\end{array}$ & $\begin{array}{l}-0.007 \\
(0.077)\end{array}$ & $\begin{array}{l}0.128^{* *} \\
(5.895)\end{array}$ & $\begin{array}{c}-0.065 \\
(-0.402)\end{array}$ & $\begin{array}{l}0.494^{* *} \\
(22.732)\end{array}$ & $\begin{array}{c}0.116 \\
(0.202)\end{array}$ & $\begin{array}{l}0.264^{* *} \\
(12.196)\end{array}$ & $\begin{array}{c}-0.497 \\
(-0.554)\end{array}$ \\
\hline Flow(-2) & $\begin{array}{c}0.166^{* *} \\
(6.895)\end{array}$ & $\begin{array}{c}0.007 \\
(0.939)\end{array}$ & $\begin{array}{c}0.093^{* *} \\
(3.873)\end{array}$ & $\begin{array}{c}0.020 \\
(0.210)\end{array}$ & $\begin{array}{l}0.065^{* *} \\
(2.961)\end{array}$ & $\begin{array}{c}0.072 \\
(0.444)\end{array}$ & $\begin{array}{l}0.131^{* *} \\
(5.412)\end{array}$ & $\begin{array}{c}-1.179 \\
(-1.839)\end{array}$ & $\begin{array}{l}0.116^{* *} \\
(5.204)\end{array}$ & $\begin{array}{c}-1.157 \\
(-1.253)\end{array}$ \\
\hline Flow(-3) & $\begin{array}{l}0.054^{*} \\
(2.243)\end{array}$ & $\begin{array}{c}-0.007 \\
(-0.931)\end{array}$ & $\begin{array}{l}0.113^{* *} \\
(4.713)\end{array}$ & $\begin{array}{l}-0.006 \\
(0.067)\end{array}$ & $\begin{array}{l}0.053^{*} \\
(2.396)\end{array}$ & $\begin{array}{c}-0.092 \\
(-0.567)\end{array}$ & $\begin{array}{l}0.075^{* *} \\
(3.079)\end{array}$ & $\begin{array}{l}1.748^{* *} \\
(2.715)\end{array}$ & $\begin{array}{l}0.112^{* *} \\
(5.014)\end{array}$ & $\begin{array}{c}0.185 \\
(0.201)\end{array}$ \\
\hline Flow(-4) & $\begin{array}{c}0.128^{* *} \\
(5.352)\end{array}$ & $\begin{array}{c}-0.007 \\
(-0.982)\end{array}$ & $\begin{array}{c}0.079^{* *} \\
(3.306)\end{array}$ & $\begin{array}{c}-0.059 \\
(-0.623)\end{array}$ & $\begin{array}{c}0.042 \\
(1.895)\end{array}$ & $\begin{array}{c}-0.145 \\
(-1.105)\end{array}$ & $\begin{array}{c}0.083^{* *} \\
(3.423)\end{array}$ & $\begin{array}{l}-1.366^{*} \\
(-2.126)\end{array}$ & $\begin{array}{c}0.103^{* *} \\
(4.456)\end{array}$ & $\begin{array}{l}-0.414 \\
(0.449)\end{array}$ \\
\hline Flow(-5) & $\begin{array}{l}0.094^{* *} \\
(4.327)\end{array}$ & $\begin{array}{c}0.012 \\
(1.816)\end{array}$ & $\begin{array}{c}0.127^{* *} \\
(5.854)\end{array}$ & $\begin{array}{c}-0.027 \\
(-0.319)\end{array}$ & $\begin{array}{c}0.004 \\
(0.205)\end{array}$ & $\begin{array}{c}0.206 \\
(1.285)\end{array}$ & $\begin{array}{l}0.088^{* *} \\
(4.061)\end{array}$ & $\begin{array}{c}0.295 \\
(0.514)\end{array}$ & $\begin{array}{l}0.096^{* *} \\
(4.456)\end{array}$ & $\begin{array}{c}-0.146 \\
(-0.163)\end{array}$ \\
\hline Return(-1) & $\begin{array}{l}-0.716^{* *} \\
(-9.822)\end{array}$ & $\begin{array}{l}-0.109^{* *} \\
(-4.900)\end{array}$ & $\begin{array}{l}-0.018^{* *} \\
(-3.229)\end{array}$ & $\begin{array}{l}-0.142^{* *} \\
(-6.465)\end{array}$ & $\begin{array}{l}-0.010^{* *} \\
(-3.403)\end{array}$ & $\begin{array}{l}-0.067^{* *} \\
(-3.057)\end{array}$ & $\begin{array}{l}-0.003^{* *} \\
(-3.920)\end{array}$ & $\begin{array}{l}-0.089^{* *} \\
(-4.096)\end{array}$ & $\begin{array}{l}-0.001^{*} \\
(-2.139)\end{array}$ & $\begin{array}{l}-0.043^{*} \\
(-1.988)\end{array}$ \\
\hline Return(-2) & $\begin{array}{c}-0.220^{* *} \\
(-2.923)\end{array}$ & $\begin{array}{l}-0.096^{* *} \\
(-4.162)\end{array}$ & $\begin{array}{l}-0.014^{*} \\
(-2.427)\end{array}$ & $\begin{array}{l}-0.084^{* *} \\
(-3.765)\end{array}$ & $\begin{array}{c}-0.002 \\
(-0.808)\end{array}$ & $\begin{array}{l}-0.071^{* *} \\
(-3.269)\end{array}$ & $\begin{array}{c}-0.001 \\
(-1.386)\end{array}$ & $\begin{array}{c}-0.080^{* *} \\
(-3.623)\end{array}$ & $\begin{array}{l}-0.001^{*} \\
(-2.482)\end{array}$ & $\begin{array}{l}-0.055^{*} \\
(-2.522)\end{array}$ \\
\hline Return(-3) & $\begin{array}{c}-0.136 \\
(-1.793)\end{array}$ & $\begin{array}{c}-0.006 \\
(-0.264)\end{array}$ & $\begin{array}{c}-0.011 \\
(-1.871)\end{array}$ & $\begin{array}{l}0.058^{* *} \\
(2.618)\end{array}$ & $\begin{array}{c}-0.004 \\
(-1.274)\end{array}$ & $\begin{array}{c}0.024 \\
(1.073)\end{array}$ & $\begin{array}{c}-0.000 \\
(-0.076)\end{array}$ & $\begin{array}{c}0.025 \\
(1.150)\end{array}$ & $\begin{array}{c}0.000 \\
(0.699)\end{array}$ & $\begin{array}{c}-0.001 \\
(-0.028)\end{array}$ \\
\hline Return(-4) & $\begin{array}{c}-0.013 \\
(-0.179)\end{array}$ & $\begin{array}{c}0.003 \\
(0.142)\end{array}$ & $\begin{array}{c}-0.004 \\
(-0.700)\end{array}$ & $\begin{array}{c}-0.016 \\
(-0.711)\end{array}$ & $\begin{array}{c}-0.002 \\
(-0.806)\end{array}$ & $\begin{array}{c}0.019 \\
(0.879)\end{array}$ & $\begin{array}{c}0.000 \\
(0.579)\end{array}$ & $\begin{array}{c}0.003 \\
(0.136)\end{array}$ & $\begin{array}{c}0.000 \\
(0.268)\end{array}$ & $\begin{array}{c}0.012 \\
(0.573)\end{array}$ \\
\hline Return(-5) & $\begin{array}{c}-0.077 \\
(-1.068)\end{array}$ & $\begin{array}{c}-0.043 \\
(-1.927)\end{array}$ & $\begin{array}{c}-0.004 \\
(-0.683)\end{array}$ & $\begin{array}{c}-0.020 \\
(-0.934)\end{array}$ & $\begin{array}{c}-0.003 \\
(-1.168)\end{array}$ & $\begin{array}{c}-0.038 \\
(-1.740)\end{array}$ & $\begin{array}{c}0.000 \\
(0.367)\end{array}$ & $\begin{array}{c}-0.031 \\
(-1.443)\end{array}$ & $\begin{array}{c}-0.000 \\
(-0.018)\end{array}$ & $\begin{array}{c}-0.042 \\
(-1.910)\end{array}$ \\
\hline
\end{tabular}

Note: Numbers in parentheses are t statistics. * and ** denote significance at the $5 \%$ and $1 \%$ levels, respectively. 
Table 5. VAR for XLE

\begin{tabular}{|c|c|c|c|c|c|c|}
\hline & \multicolumn{2}{|c|}{$\begin{array}{c}\text { Before GFC } \\
(2005 / 11 / 1 \sim 2008 / 07 / 31)\end{array}$} & \multicolumn{2}{|c|}{$\begin{array}{c}\text { During GFC } \\
(2008 / 08 / 01 \sim 2009 / 03 / 31)\end{array}$} & \multicolumn{2}{|c|}{$\begin{array}{c}\text { After GFC } \\
(2009 / 04 / 01 \sim 2014 / 01 / 03)\end{array}$} \\
\hline & XLE_Flow & XLE_Return & XLE_Flow & XLE_Return & XLE_Flow & XLE_Return \\
\hline C & $\begin{array}{l}8.184^{* *} \\
(7.334)\end{array}$ & $\begin{array}{c}0.200 \\
(0.803)\end{array}$ & $\begin{array}{c}11.737^{* *} \\
(3.844)\end{array}$ & $\begin{array}{c}-1.237 \\
(-0.853)\end{array}$ & $\begin{array}{c}2.465^{* *} \\
(6.344)\end{array}$ & $\begin{array}{c}0.028 \\
(0.241)\end{array}$ \\
\hline XLE_Flow(-1) & $\begin{array}{l}0.361^{* *} \\
(9.087)\end{array}$ & $\begin{array}{c}0.002 \\
(0.186)\end{array}$ & $\begin{array}{l}0.462^{* *} \\
(5.846)\end{array}$ & $\begin{array}{c}-0.017 \\
(-0.459)\end{array}$ & $\begin{array}{l}0.412^{* *} \\
(14.218)\end{array}$ & $\begin{array}{l}-0.018^{*} \\
(-2.043)\end{array}$ \\
\hline XLE_Flow(-2) & $\begin{array}{c}0.082 \\
(1.935)\end{array}$ & $\begin{array}{c}-0.011 \\
(-1.113)\end{array}$ & $\begin{array}{l}0.233^{* *} \\
(2.701)\end{array}$ & $\begin{array}{c}0.058 \\
(1.408)\end{array}$ & $\begin{array}{l}0.170^{* *} \\
(5.454)\end{array}$ & $\begin{array}{c}0.014 \\
(1.495)\end{array}$ \\
\hline XLE_Flow(-3) & $\begin{array}{c}0.041 \\
(0.981)\end{array}$ & $\begin{array}{l}-0.008 \\
(0.875)\end{array}$ & $\begin{array}{c}-0.095 \\
(-1.075)\end{array}$ & $\begin{array}{c}-0.010 \\
(-0.237)\end{array}$ & $\begin{array}{c}0.045 \\
(1.429)\end{array}$ & $\begin{array}{c}-0.008 \\
(-0.842)\end{array}$ \\
\hline XLE_Flow(-4) & $\begin{array}{l}0.120^{* *} \\
(2.854)\end{array}$ & $\begin{array}{c}-0.012 \\
(-1.306)\end{array}$ & $\begin{array}{c}0.104 \\
(1.221)\end{array}$ & $\begin{array}{c}-0.012 \\
(-0.296)\end{array}$ & $\begin{array}{l}0.099 * * \\
(3.172)\end{array}$ & $\begin{array}{c}0.006 \\
(0.662)\end{array}$ \\
\hline XLE_Flow(-5) & $\begin{array}{c}0.054 \\
(1.416)\end{array}$ & $\begin{array}{l}0.024^{* *} \\
(2.810)\end{array}$ & $\begin{array}{c}0.010 \\
(0.127)\end{array}$ & $\begin{array}{c}0.001 \\
(0.025)\end{array}$ & $\begin{array}{l}0.125^{* *} \\
(4.384)\end{array}$ & $\begin{array}{c}0.008 \\
(0.906)\end{array}$ \\
\hline XLE_Return(-1) & $\begin{array}{l}-0.921^{* *} \\
(-5.189)\end{array}$ & $\begin{array}{l}-0.122^{* *} \\
(-3.076)\end{array}$ & $\begin{array}{l}-0.590^{* *} \\
(-3.506)\end{array}$ & $\begin{array}{l}-0.166^{*} \\
(-2.076)\end{array}$ & $\begin{array}{l}-0.721^{* *} \\
(-7.320)\end{array}$ & $\begin{array}{c}-0.017 \\
(-0.574)\end{array}$ \\
\hline XLE_Return(-2) & $\begin{array}{l}-0.210 \\
(-1.134)\end{array}$ & $\begin{array}{c}-0.051 \\
(-1.237)\end{array}$ & $\begin{array}{c}-0.306 \\
(-1.725)\end{array}$ & $\begin{array}{l}-0.226^{* *} \\
(-2.678)\end{array}$ & $\begin{array}{l}-0.200^{*} \\
(-1.998)\end{array}$ & $\begin{array}{c}0.047 \\
(1.589)\end{array}$ \\
\hline XLE_Return(-3) & $\begin{array}{l}-0.485^{* *} \\
(-2.633)\end{array}$ & $\begin{array}{c}-0.006 \\
(-1.542)\end{array}$ & $\begin{array}{c}-0.127 \\
(-0.686)\end{array}$ & $\begin{array}{c}0.096 \\
(1.095)\end{array}$ & $\begin{array}{c}-0.059 \\
(-0.588)\end{array}$ & $\begin{array}{l}-0.103^{* *} \\
(-3.475)\end{array}$ \\
\hline XLE_Return(-4) & $\begin{array}{c}-0.049 \\
(-0.264)\end{array}$ & $\begin{array}{l}-0.010 \\
(0.239)\end{array}$ & $\begin{array}{c}-0.214 \\
(-1.192)\end{array}$ & $\begin{array}{c}0.021 \\
(0.249)\end{array}$ & $\begin{array}{c}-0.006 \\
(-0.057)\end{array}$ & $\begin{array}{c}0.016 \\
(0.560)\end{array}$ \\
\hline XLE_Return(-5) & $\begin{array}{c}-0.105 \\
(-0.592)\end{array}$ & $\begin{array}{c}-0.025 \\
(-0.628)\end{array}$ & $\begin{array}{l}-0.346^{*} \\
(-2.002)\end{array}$ & $\begin{array}{c}0.009 \\
(0.108)\end{array}$ & $\begin{array}{c}0.064 \\
(0.654)\end{array}$ & $\begin{array}{c}-0.040 \\
(-1.401)\end{array}$ \\
\hline
\end{tabular}

Note: Numbers in parentheses are t statistics. * and ${ }^{* *}$ denote significance at the $5 \%$ and $1 \%$ levels, respectively. 
Table 6. VAR for IYE

\begin{tabular}{|c|c|c|c|c|c|c|}
\hline & \multicolumn{2}{|c|}{$\begin{array}{c}\text { Before GFC } \\
(2005 / 11 / 1 \sim 2008 / 07 / 31)\end{array}$} & \multicolumn{2}{|c|}{$\begin{array}{c}\text { During GFC } \\
(2008 / 08 / 01 \sim 2009 / 03 / 31)\end{array}$} & \multicolumn{2}{|c|}{$\begin{array}{c}\text { After GFC } \\
(2009 / 04 / 01 \sim 2014 / 01 / 03)\end{array}$} \\
\hline & IYE_Flow & IYE_Return & IYE_Flow & IYE_Return & IYE_Flow & IYE_Return \\
\hline C & $\begin{array}{c}0.063^{* *} \\
(2.692)\end{array}$ & $\begin{array}{c}0.140 \\
(1.770)\end{array}$ & $\begin{array}{c}0.196 \\
(1.765)\end{array}$ & $\begin{array}{c}-1.007 \\
(-1.270)\end{array}$ & $\begin{array}{c}0.199 * * \\
(9.855)\end{array}$ & $\begin{array}{c}0.010 \\
(0.169)\end{array}$ \\
\hline IYE_Flow(-1) & $\begin{array}{l}0.504^{* *} \\
(13.221)\end{array}$ & $\begin{array}{c}-0.007 \\
(-0.052)\end{array}$ & $\begin{array}{l}0.412^{* *} \\
(5.041)\end{array}$ & $\begin{array}{c}0.228 \\
(0.390)\end{array}$ & $\begin{array}{l}0.345^{* *} \\
(12.140)\end{array}$ & $\begin{array}{c}0.027 \\
(0.306)\end{array}$ \\
\hline IYE_Flow(-2) & $\begin{array}{l}0.177^{* *} \\
(4.123)\end{array}$ & $\begin{array}{c}-0.146 \\
(-0.994)\end{array}$ & $\begin{array}{l}0.207^{*} \\
(2.373)\end{array}$ & $\begin{array}{c}0.509 \\
(0.814)\end{array}$ & $\begin{array}{c}-0.043 \\
(-1.434)\end{array}$ & $\begin{array}{c}0.075 \\
(0.815)\end{array}$ \\
\hline IYE_Flow(-3) & $\begin{array}{l}0.115^{* *} \\
(2.663)\end{array}$ & $\begin{array}{c}-0.005 \\
(-0.032)\end{array}$ & $\begin{array}{c}0.054 \\
(0.599)\end{array}$ & $\begin{array}{c}0.216 \\
(0.338)\end{array}$ & $\begin{array}{c}0.046 \\
(1.538)\end{array}$ & $\begin{array}{c}0.014 \\
(0.147)\end{array}$ \\
\hline IYE_Flow(-4) & $\begin{array}{c}0.055 \\
(1.282)\end{array}$ & $\begin{array}{c}-0.058 \\
(-0.393)\end{array}$ & $\begin{array}{c}0.156 \\
(1.794)\end{array}$ & $\begin{array}{c}-0.963 \\
(-1.550)\end{array}$ & $\begin{array}{c}-0.008 \\
(-0.275)\end{array}$ & $\begin{array}{c}0.171 \\
(1.855)\end{array}$ \\
\hline IYE_Flow(-5) & $\begin{array}{c}0.067 \\
(1.758)\end{array}$ & $\begin{array}{c}0.120 \\
(0.918)\end{array}$ & $\begin{array}{c}0.036 \\
(0.450)\end{array}$ & $\begin{array}{c}0.376 \\
(0.648)\end{array}$ & $\begin{array}{l}0.067^{*} \\
(2.356)\end{array}$ & $\begin{array}{c}-0.142 \\
(-1.639)\end{array}$ \\
\hline IYE _Return(-1) & $\begin{array}{c}-0.011 \\
(-1.017)\end{array}$ & $\begin{array}{c}-0.007 \\
(-1.820)\end{array}$ & $\begin{array}{l}-0.025^{*} \\
(-2.166)\end{array}$ & $\begin{array}{l}-0.248^{* *} \\
(-3.051)\end{array}$ & $\begin{array}{c}-0.013 \\
(-1.377)\end{array}$ & $\begin{array}{c}-0.018 \\
(-0.647)\end{array}$ \\
\hline IYE _Return(-2) & $\begin{array}{c}0.007 \\
(0.575)\end{array}$ & $\begin{array}{c}-0.049 \\
(-1.269)\end{array}$ & $\begin{array}{l}-0.025^{*} \\
(-2.079)\end{array}$ & $\begin{array}{l}-0.201^{*} \\
(-2.344)\end{array}$ & $\begin{array}{c}-0.011 \\
(-1.214)\end{array}$ & $\begin{array}{l}0.061^{*} \\
(2.134)\end{array}$ \\
\hline IYE_Return(-3) & $\begin{array}{c}-0.007 \\
(-0.605)\end{array}$ & $\begin{array}{c}-0.040 \\
(-1.029)\end{array}$ & $\begin{array}{c}-0.020 \\
(-1.650)\end{array}$ & $\begin{array}{l}0.201^{*} \\
(2.271)\end{array}$ & $\begin{array}{c}-0.002 \\
(-0.164)\end{array}$ & $\begin{array}{l}-0.098^{* *} \\
(-3.466)\end{array}$ \\
\hline IYE_Return(-4) & $\begin{array}{c}-0.004 \\
(-0.383)\end{array}$ & $\begin{array}{c}0.029 \\
(0.741)\end{array}$ & $\begin{array}{c}-0.008 \\
(-0.669)\end{array}$ & $\begin{array}{c}-0.004 \\
(-0.045)\end{array}$ & $\begin{array}{c}0.005 \\
(0.551)\end{array}$ & $\begin{array}{c}0.022 \\
(0.774)\end{array}$ \\
\hline IYE_Return(-5) & $\begin{array}{c}0.008 \\
(0.738)\end{array}$ & $\begin{array}{c}-0.036 \\
(-0.937)\end{array}$ & $\begin{array}{c}-0.002 \\
(-0.164)\end{array}$ & $\begin{array}{c}0.072 \\
(0.911)\end{array}$ & $\begin{array}{c}-0.016 \\
(-1.711)\end{array}$ & $\begin{array}{c}-0.045 \\
(-1.595)\end{array}$ \\
\hline
\end{tabular}

Note: Numbers in parentheses are t statistics. * and ** denote significance at the $5 \%$ and $1 \%$ levels, respectively. 
Table 7. VAR for IXC

\begin{tabular}{|c|c|c|c|c|c|c|}
\hline & \multicolumn{2}{|c|}{$\begin{array}{c}\text { Before GFC } \\
(2005 / 11 / 1 \sim 2008 / 07 / 31)\end{array}$} & \multicolumn{2}{|c|}{$\begin{array}{c}\text { During GFC } \\
(2008 / 08 / 01 \sim 2009 / 03 / 31) \\
\end{array}$} & \multicolumn{2}{|c|}{$\begin{array}{c}\text { After GFC } \\
(2009 / 04 / 01 \sim 2014 / 01 / 03) \\
\end{array}$} \\
\hline & IXC_Flow & IXC_Return & IXC_Flow & IXC_Return & IXC_Flow & IXC_Return \\
\hline \multirow{2}{*}{ C } & $0.175^{* *}$ & 0.015 & $0.098^{* *}$ & -0.147 & $0.117^{* *}$ & 0.040 \\
\hline & (9.359) & $(0.182)$ & (3.556) & $(-0.221)$ & $(10.255)$ & $(0.537)$ \\
\hline \multirow{2}{*}{ IXC_Flow(-1) } & $0.080^{*}$ & 0.109 & 0.104 & -1.040 & $0.168^{* *}$ & -0.082 \\
\hline & (2.104) & $(0.638)$ & $(1.342)$ & $(-0.560)$ & $(5.862)$ & $(-0.436)$ \\
\hline \multirow{2}{*}{ IXC_Flow(-2) } & 0.049 & -0.004 & 0.080 & 2.522 & $0.076^{* *}$ & -0.027 \\
\hline & (1.281) & $(-0.023)$ & (1.036) & (1.355) & $(2.620)$ & $(-0.143)$ \\
\hline \multirow{2}{*}{ IXC_Flow(-3) } & 0.022 & -0.165 & 0.079 & 1.117 & $0.067^{*}$ & -0.179 \\
\hline & $(0.587)$ & $(-0.961)$ & (1.024) & $(0.598)$ & $(2.322)$ & $(-0.939)$ \\
\hline \multirow{2}{*}{ IXC_Flow(-4) } & -0.028 & 0.087 & 0.056 & -1.443 & $0.102^{* *}$ & -0.225 \\
\hline & $(-0.747)$ & $(0.505)$ & $(0.729)$ & $(-0.775)$ & $(3.545)$ & $(-1.181)$ \\
\hline \multirow{2}{*}{ IXC_Flow(-5) } & -0.009 & 0.138 & 0.105 & -2.300 & 0.002 & $0.515^{* *}$ \\
\hline & $(-0.228)$ & $(0.815)$ & (1.364) & $(-1.241)$ & $(0.058)$ & $(2.734)$ \\
\hline \multirow{2}{*}{ IXC _Return(-1) } & $-0.032^{* *}$ & -0.009 & -0.004 & -0.124 & -0.007 & -0.020 \\
\hline & $(-3.879)$ & $(-0.231)$ & $(-1.226)$ & $(-1.587)$ & $(-1.509)$ & $(-0.718)$ \\
\hline \multirow{2}{*}{ IXC _Return(-2) } & -0.009 & -0.019 & -0.001 & $-0.207^{* *}$ & 0.001 & $0.068^{*}$ \\
\hline & $(-1.018)$ & $(-0.492)$ & $(-0.247)$ & $(-2.620)$ & $(0.257)$ & $(2.384)$ \\
\hline \multirow{2}{*}{ IXC _Return(-3) } & -0.004 & -0.019 & -0.004 & 0.118 & -0.004 & $-0.092^{* *}$ \\
\hline & $(-0.492)$ & $(-0.507)$ & $(-1.069)$ & (1.465) & $(-0.954)$ & $(-3.247)$ \\
\hline \multirow{2}{*}{ IXC _Return(-4) } & -0.011 & 0.059 & 0.001 & -0.003 & -0.004 & 0.008 \\
\hline & $(-1.276)$ & (1.549) & $(0.446)$ & $(-0.032)$ & $(-0.962)$ & $(0.288)$ \\
\hline \multirow{2}{*}{ IXC_Return(-5) } & -0.008 & 0.002 & $-0.007^{*}$ & 0.001 & 0.003 & -0.039 \\
\hline & $(-0.993)$ & $(0.040)$ & & $(-0.221)$ & $(0.738)$ & $(-1.358)$ \\
\hline
\end{tabular}

Note: Numbers in parentheses are t statistics. * and ** denote significance at the $5 \%$ and $1 \%$ levels, respectively. 
Table 8. VAR for VDE

\begin{tabular}{|c|c|c|c|c|c|c|}
\hline & \multicolumn{2}{|c|}{$\begin{array}{c}\text { Before GFC } \\
(2005 / 11 / 1 \sim 2008 / 07 / 31) \\
\end{array}$} & \multicolumn{2}{|c|}{$\begin{array}{c}\text { During GFC } \\
(2008 / 08 / 01 \sim 2009 / 03 / 31) \\
\end{array}$} & \multicolumn{2}{|c|}{$\begin{array}{c}\text { After GFC } \\
(2009 / 04 / 01 \sim 2014 / 01 / 03) \\
\end{array}$} \\
\hline & VDE_Flow & VDE_Return & VDE_Flow & VDE_Return & VDE_Flow & VDE_Return \\
\hline \multirow{2}{*}{ C } & $0.021^{* *}$ & 0.211 & $0.068^{* *}$ & -0.982 & $0.026^{* *}$ & 0.061 \\
\hline & $(5.645)$ & (1.789) & $(2.930)$ & $(-1.082)$ & $(6.097)$ & $(0.741)$ \\
\hline \multirow{2}{*}{ VDE_Flow(-1) } & $0.143^{* *}$ & -1.529 & $0.524^{* *}$ & 3.354 & $0.544^{* *}$ & -0.312 \\
\hline & (3.797) & $(-1.262)$ & (6.712) & (1.105) & (18.829) & $(-0.557)$ \\
\hline \multirow{2}{*}{ VDE_Flow(-2) } & $0.148^{* *}$ & -1.668 & 0.057 & 0.007 & $0.101^{* *}$ & -0.777 \\
\hline & (3.882) & $(-1.369)$ & $(0.644)$ & $(0.002)$ & (3.100) & $(-1.226)$ \\
\hline \multirow{2}{*}{ VDE_Flow(-3) } & $0.186^{* *}$ & $2.748^{*}$ & 0.009 & 3.614 & 0.049 & 0.250 \\
\hline & $(4.877)$ & (2.249) & $(0.106)$ & (1.062) & (1.492) & $(0.394)$ \\
\hline \multirow{2}{*}{ VDE_Flow(-4) } & 0.053 & -1.465 & 0.054 & -3.376 & $0.094^{* *}$ & -0.266 \\
\hline & (1.385) & $(-1.193)$ & $(0.625)$ & $(-1.009)$ & $(2.876)$ & $(-0.420)$ \\
\hline \multirow{2}{*}{ VDE_Flow(-5) } & $0.115^{*}$ & -0.646 & 0.074 & -1.423 & 0.053 & $1.122^{*}$ \\
\hline & $(2.447)$ & $(-0.428)$ & $(1.032)$ & $(-0.512)$ & (1.849) & (2.015) \\
\hline \multirow{2}{*}{ VDE_Return(-1) } & $-0.004^{* *}$ & -0.044 & -0.003 & $-0.190^{*}$ & -0.003 & -0.014 \\
\hline & $(-3.385)$ & $(-1.160)$ & $(-1.433)$ & $(-2.423)$ & $(-1.812)$ & $(-0.467)$ \\
\hline \multirow{2}{*}{ VDE_Return(-2) } & $-0.004^{* *}$ & -0.052 & 0.001 & $-0.201^{*}$ & -0.001 & 0.041 \\
\hline & $(-3.039)$ & $(-1.355)$ & $(0.434)$ & $(-2.518)$ & $(-0.719)$ & $(1.439)$ \\
\hline \multirow{2}{*}{ VDE_Return(-3) } & -0.002 & -0.044 & 0.000 & 0.104 & 0.000 & $-0.108^{* *}$ \\
\hline & $(-1.422)$ & $(-1.144)$ & $(0.020)$ & (1.284) & $(0.213)$ & $(-3.793)$ \\
\hline \multirow{2}{*}{ VDE_Return(-4) } & 0.002 & 0.035 & 0.002 & -0.002 & -0.002 & 0.013 \\
\hline & (1.418) & $(0.895)$ & $(0.748)$ & $(-0.030)$ & $(-1.276)$ & $(0.459)$ \\
\hline \multirow{2}{*}{ VDE_Return(-5) } & -0.000 & -0.031 & -0.001 & 0.007 & $0.003^{*}$ & -0.035 \\
\hline & $(-0.362)$ & $(-0.806)$ & $(-0.706)$ & $(0.093)$ & (2.096) & $(-1.239)$ \\
\hline
\end{tabular}

Note: Numbers in parentheses are t statistics. * and ${ }^{* *}$ denote significance at the $5 \%$ and $1 \%$ levels, respectively. 
Table 9. VAR for PXE

\begin{tabular}{|c|c|c|c|c|c|c|}
\hline & \multicolumn{2}{|c|}{$\begin{array}{c}\text { Before GFC } \\
(2005 / 11 / 1 \sim 2008 / 07 / 31) \\
\end{array}$} & \multicolumn{2}{|c|}{$\begin{array}{c}\text { During GFC } \\
(2008 / 08 / 01 \sim 2009 / 03 / 31) \\
\end{array}$} & \multicolumn{2}{|c|}{$\begin{array}{c}\text { After GFC } \\
(2009 / 04 / 01 \sim 2014 / 01 / 03) \\
\end{array}$} \\
\hline & PXE_Flow & PXE_Return & PXE_Flow & PXE_Return & PXE_Flow & PXE_Return \\
\hline \multirow{2}{*}{ C } & $0.035^{* *}$ & $0.275^{*}$ & $0.037^{* *}$ & -0.136 & $0.020^{* *}$ & 0.167 \\
\hline & (6.686) & $(2.106)$ & $(4.002)$ & $(-0.153)$ & (9.599) & (1.952) \\
\hline \multirow{2}{*}{ PXE_Flow(-1) } & $0.300^{* *}$ & -0.395 & 0.063 & 4.644 & $0.165^{* *}$ & -1.732 \\
\hline & (7.970) & $(-0.416)$ & $(0.808)$ & $(0.620)$ & (5.788) & $(-1.448)$ \\
\hline \multirow{2}{*}{ PXE_Flow(-2) } & $0.078^{*}$ & $-2.354^{*}$ & 0.046 & -0.325 & $0.083^{* *}$ & -0.104 \\
\hline & (1.989) & $(-2.385)$ & $(0.589)$ & $(-0.043)$ & $(2.902)$ & $(-0.086)$ \\
\hline \multirow{2}{*}{ PXE_Flow(-3) } & $0.109^{* *}$ & -0.672 & 0.037 & 5.089 & 0.036 & 0.562 \\
\hline & $(2.794)$ & $(-0.684)$ & $(0.478)$ & $(0.680)$ & (1.252) & $(0.464)$ \\
\hline \multirow{2}{*}{ PXE_Flow(-4) } & 0.059 & -0.966 & 0.041 & -6.809 & $0.084^{* *}$ & 1.053 \\
\hline & $(1.503)$ & $(-0.983)$ & $(0.531)$ & $(-0.916)$ & $(2.941)$ & $(0.872)$ \\
\hline \multirow{2}{*}{ PXE_Flow(-5) } & 0.063 & $1.994^{*}$ & 0.092 & -9.150 & $0.064^{*}$ & -1.997 \\
\hline & (1.693) & (2.120) & (1.196) & $(-1.231)$ & $(2.256)$ & $(-1.674)$ \\
\hline \multirow{2}{*}{ PXE _Return(-1) } & $-0.003^{*}$ & 0.007 & -0.000 & -0.114 & $-0.002^{*}$ & 0.011 \\
\hline & $(-2.301)$ & $(0.186)$ & $(-0.021)$ & $(-1.458)$ & $(-2.448)$ & $(0.382)$ \\
\hline \multirow{2}{*}{ PXE _Return(-2) } & -0.003 & -0.044 & -0.001 & $-0.159^{*}$ & -0.001 & 0.053 \\
\hline & $(-1.873)$ & $(-1.156)$ & $(-1.524)$ & $(-2.030)$ & $(-1.097)$ & $(1.875)$ \\
\hline \multirow{2}{*}{ PXE _Return(-3) } & $0.004^{*}$ & -0.048 & -0.001 & 0.099 & -0.001 & $-0.116^{* *}$ \\
\hline & (2.409) & $(-1.260)$ & $(-0.896)$ & (1.241) & $(-1.119)$ & $(-4.104)$ \\
\hline \multirow{2}{*}{ PXE_Return(-4) } & -0.002 & 0.051 & 0.000 & 0.001 & -0.000 & 0.008 \\
\hline & $(-1.478)$ & (1.350) & (0.179) & $(0.012)$ & $(-0.174)$ & $(0.285)$ \\
\hline \multirow{2}{*}{ PXE_Return(-5) } & 0.001 & -0.025 & -0.001 & -0.030 & 0.000 & -0.054 \\
\hline & $(0.567)$ & $(-0.659)$ & $(-1.261)$ & $(-0.038)$ & $(0.688)$ & $(-1.919)$ \\
\hline
\end{tabular}

Note: Numbers in parentheses are t statistics. * and ${ }^{* *}$ denote significance at the $5 \%$ and $1 \%$ levels, respectively. 
Table 10. VAR for unexpected flow

\begin{tabular}{|c|c|c|c|c|c|c|c|c|c|c|}
\hline & \multicolumn{2}{|c|}{ XLE } & \multicolumn{2}{|c|}{ IYE } & \multicolumn{2}{|c|}{ IXC } & \multicolumn{2}{|c|}{ VDE } & \multicolumn{2}{|c|}{ PXE } \\
\hline & UFlow & Return & UFlow & Return & UFlow & Return & UFlow & Return & UFlow & Return \\
\hline \multirow{2}{*}{$\mathbf{C}$} & 0.026 & 0.034 & 0.001 & 0.033 & 0.000 & 0.017 & 0.000 & 0.031 & 0.000 & 0.040 \\
\hline & $(0.180)$ & $(0.787)$ & $(0.111)$ & $(0.791)$ & $(0.057)$ & $(0.423)$ & $(0.100)$ & $(0.728)$ & $(0.087)$ & (0.823) \\
\hline \multirow{2}{*}{ UFlow(-1) } & $-0.278^{* *}$ & -0.012 & $-0.218^{* *}$ & -0.026 & -0.026 & -0.064 & $-0.207^{* *}$ & 0.019 & $-0.137^{* *}$ & -0.519 \\
\hline & $(-12.613)$ & $(-1.839)$ & $(-10.083)$ & $(0.318)$ & $(-1.206)$ & $(-0.400)$ & $(-9.525)$ & $(0.034)$ & $(-6.332)$ & $(-0.585)$ \\
\hline \multirow{2}{*}{ UFlow(-2) } & -0.022 & -0.002 & -0.042 & -0.009 & $0.061^{* *}$ & 0.063 & -0.003 & $-1.192^{*}$ & $0.074^{* *}$ & -1.397 \\
\hline & $(-0.959)$ & $(-0.347)$ & $(-1.911)$ & $(-0.109)$ & $(2.827)$ & $(0.394)$ & $(-0.142)$ & $(-2.098)$ & (3.440) & $(-1.580)$ \\
\hline \multirow{2}{*}{ UFlow(-3) } & 0.043 & -0.009 & $0.094^{* *}$ & -0.019 & $0.063^{* *}$ & -0.081 & $0.078^{* *}$ & 0.861 & $0.153^{* *}$ & -0.421 \\
\hline & $(1.875)$ & $(-1.286)$ & (4.289) & $(-0.233)$ & (2.887) & $(-0.501)$ & (3.535) & (1.518) & (7.197) & $(-0.481)$ \\
\hline \multirow{2}{*}{ UFlow(-4) } & $0.147^{* *}$ & $-0.014^{*}$ & $0.134^{* *}$ & -0.072 & $0.051^{*}$ & -0.155 & $0.123^{* *}$ & -0.637 & $0.165^{* *}$ & -0.608 \\
\hline & (6.474) & $(-2.032)$ & (6.133) & $(-0.862)$ & (2.351) & $(-0.965)$ & (5.590) & $(-1.120)$ & (7.699) & $(-0.689)$ \\
\hline \multirow{2}{*}{ UFlow(-5) } & $0.132^{* *}$ & 0.002 & $0.161^{* *}$ & -0.078 & 0.003 & 0.184 & $0.086^{* *}$ & 0.187 & $0.121^{* *}$ & -0.428 \\
\hline & $(6.061)$ & $(0.346)$ & (7.487) & $(-0.942)$ & $(0.145)$ & (1.148) & (3.973) & (0.333) & (5.636) & $(-0.484)$ \\
\hline \multirow{2}{*}{ Return(-1) } & $-0.664^{* *}$ & $-0.109^{* *}$ & $-0.017^{* *}$ & $-0.142^{* *}$ & $-0.010^{* *}$ & $-0.066^{* *}$ & $-0.003^{* *}$ & $-0.089^{* *}$ & $-0.001^{*}$ & $-0.043^{*}$ \\
\hline & $(-8.844)$ & $(-4.890)$ & $(-3.036)$ & $(-6.474)$ & $(-3.407)$ & $(-3.051)$ & $(-3.765)$ & $(-4.091)$ & $(-2.139)$ & $(-1.988)$ \\
\hline \multirow{2}{*}{ Return(-2) } & -0.137 & $-0.095^{* *}$ & $-0.012^{*}$ & $-0.084^{* *}$ & -0.002 & $-0.072^{* *}$ & -0.001 & $-0.081^{* *}$ & $-0.001^{*}$ & $-0.055^{*}$ \\
\hline & $(-1.769)$ & $(-4.161)$ & $(-2.062)$ & $(-3.789)$ & $(-0.810)$ & $(-3.270)$ & $(-0.993)$ & $(-3.668)$ & $(-2.451)$ & $(-2.522)$ \\
\hline \multirow{2}{*}{ Return(-3) } & -0.055 & -0.006 & -0.008 & $0.057^{* *}$ & -0.004 & 0.024 & 0.000 & 0.026 & 0.000 & -0.001 \\
\hline & $(-0.714)$ & $(-0.248)$ & $(-1.417)$ & (2.583) & $(-1.268)$ & (1.072) & $(0.219)$ & (1.158) & $(0.705)$ & $(-0.031)$ \\
\hline \multirow{2}{*}{ Return(-4) } & 0.047 & 0.004 & -0.002 & -0.017 & -0.002 & 0.019 & 0.001 & 0.003 & 0.000 & 0.013 \\
\hline & (0.613) & (0.174) & $(-0.296)$ & $(-0.752)$ & $(-0.803)$ & (0.883) & $(0.673)$ & $(0.133)$ & $(0.217)$ & $(0.575)$ \\
\hline \multirow{2}{*}{ Return(-5) } & -0.088 & -0.041 & -0.003 & -0.021 & -0.004 & -0.038 & 0.000 & -0.030 & -0.000 & -0.042 \\
\hline & $(-1.160)$ & $(-1.832)$ & $(-0.608)$ & $(-0.966)$ & $(-1.191)$ & $(-1.738)$ & $(0.077)$ & $(-1.370)$ & $(-0.112)$ & $(-1.910)$ \\
\hline
\end{tabular}

Note: Numbers in parentheses are t statistics. * and ${ }^{* *}$ denote significance at the $5 \%$ and $1 \%$ levels, respectively. 
Figure 1. XLE returns (2005/11/01 - 2014/01/03)

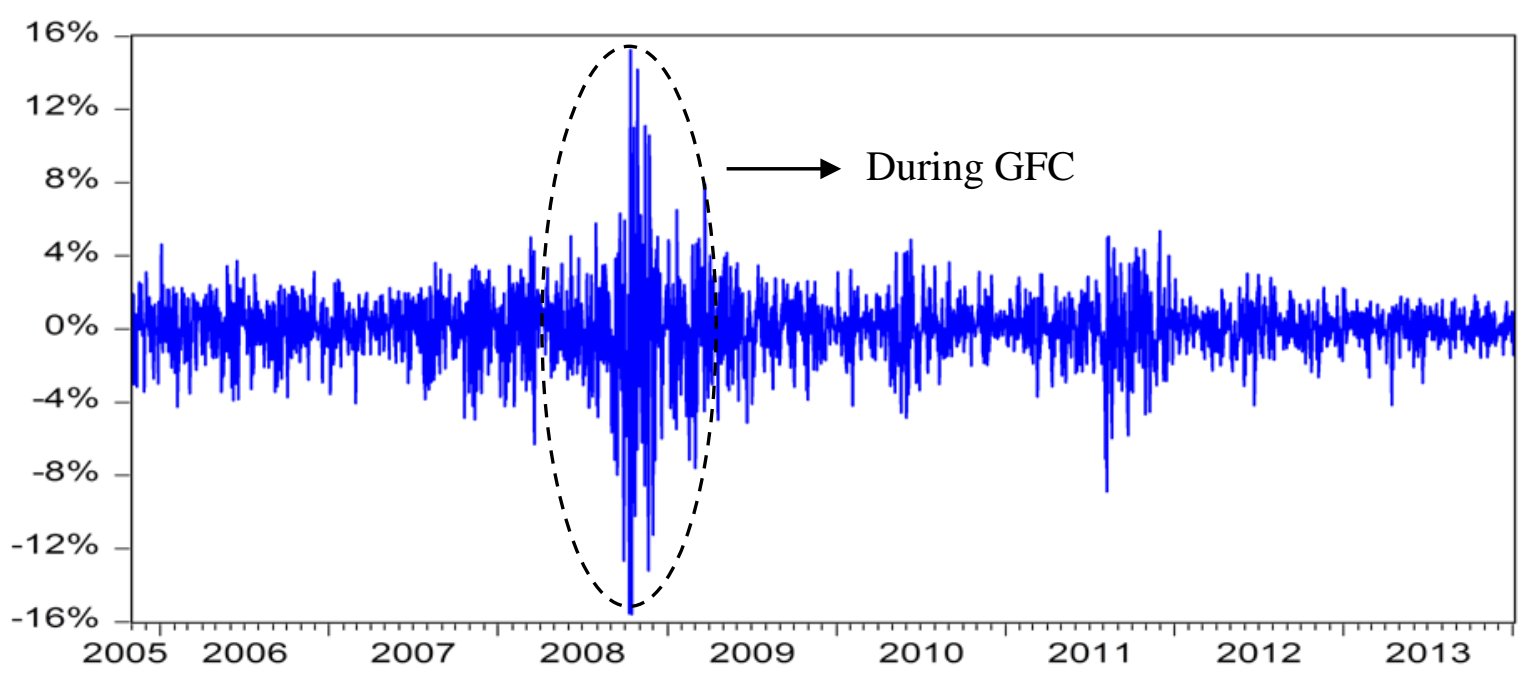

Figure 2. IYE returns (2005/11/01 - 2014/01/03)

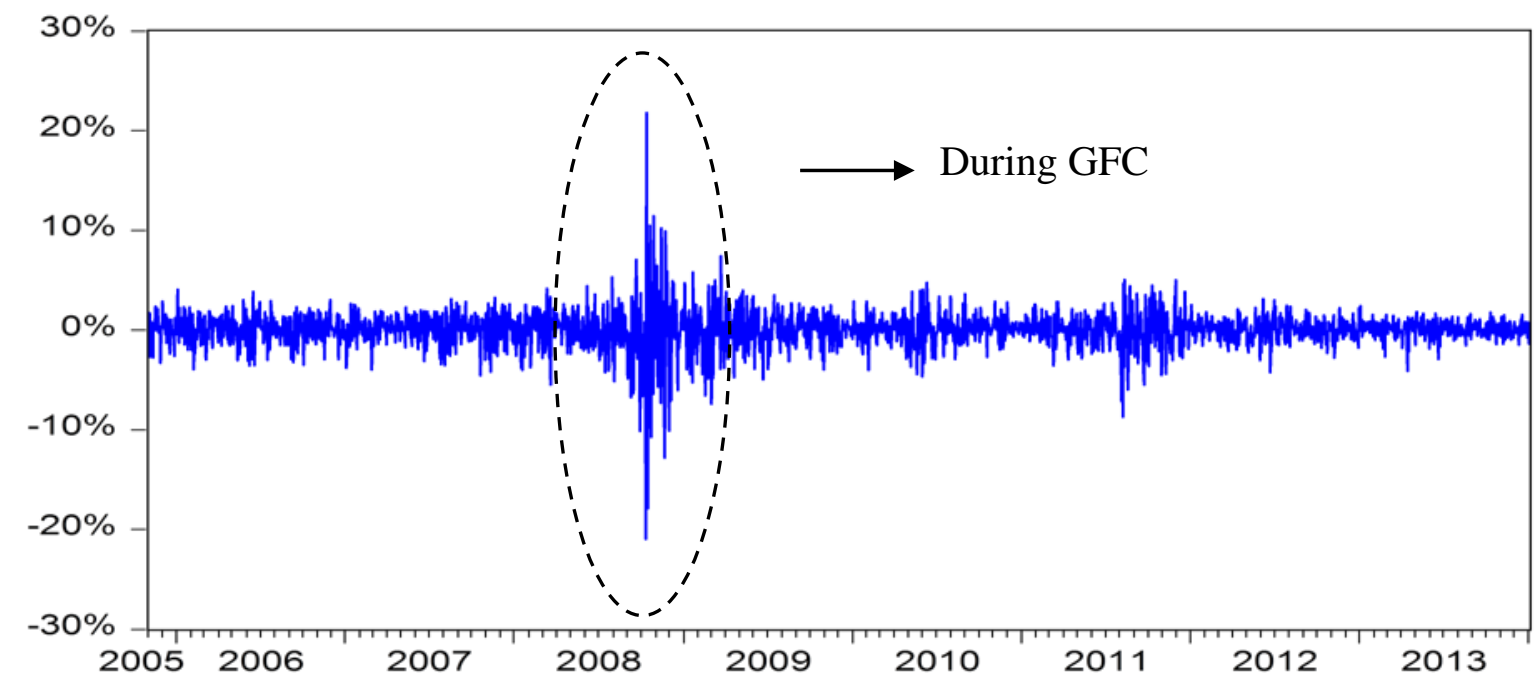


Figure 3. IXE returns (2005/11/01 - 2014/01/03)

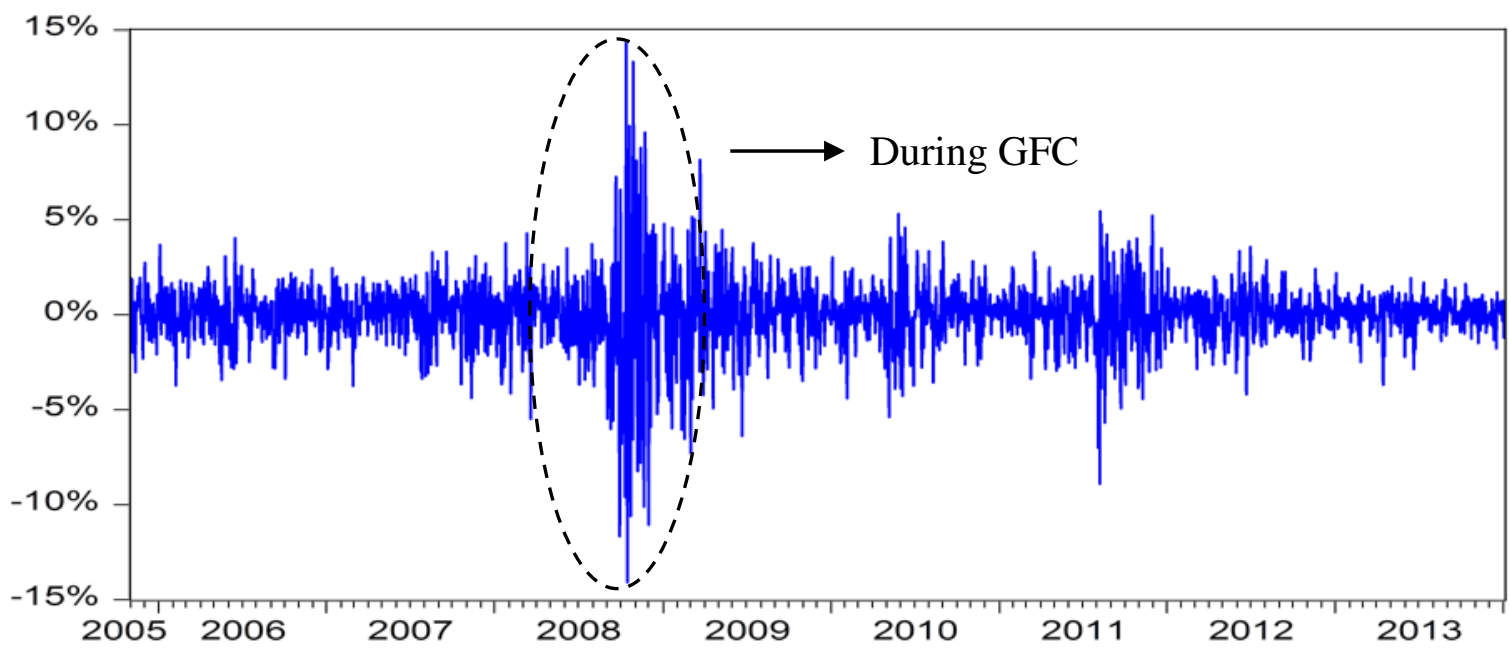

Figure 4. VDE returns (2005/11/01 - 2014/01/03)

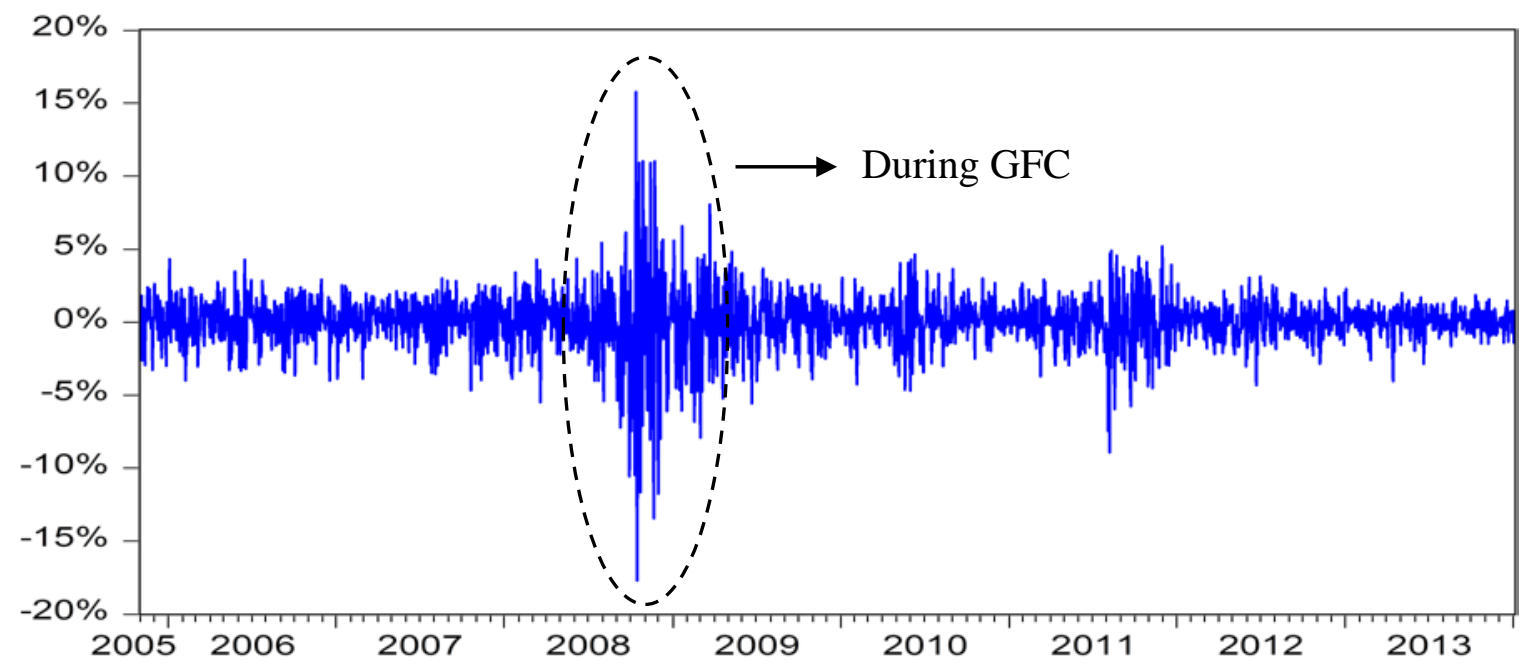


Figure 5. PXE returns (2005/11/01 - 2014/01/03)

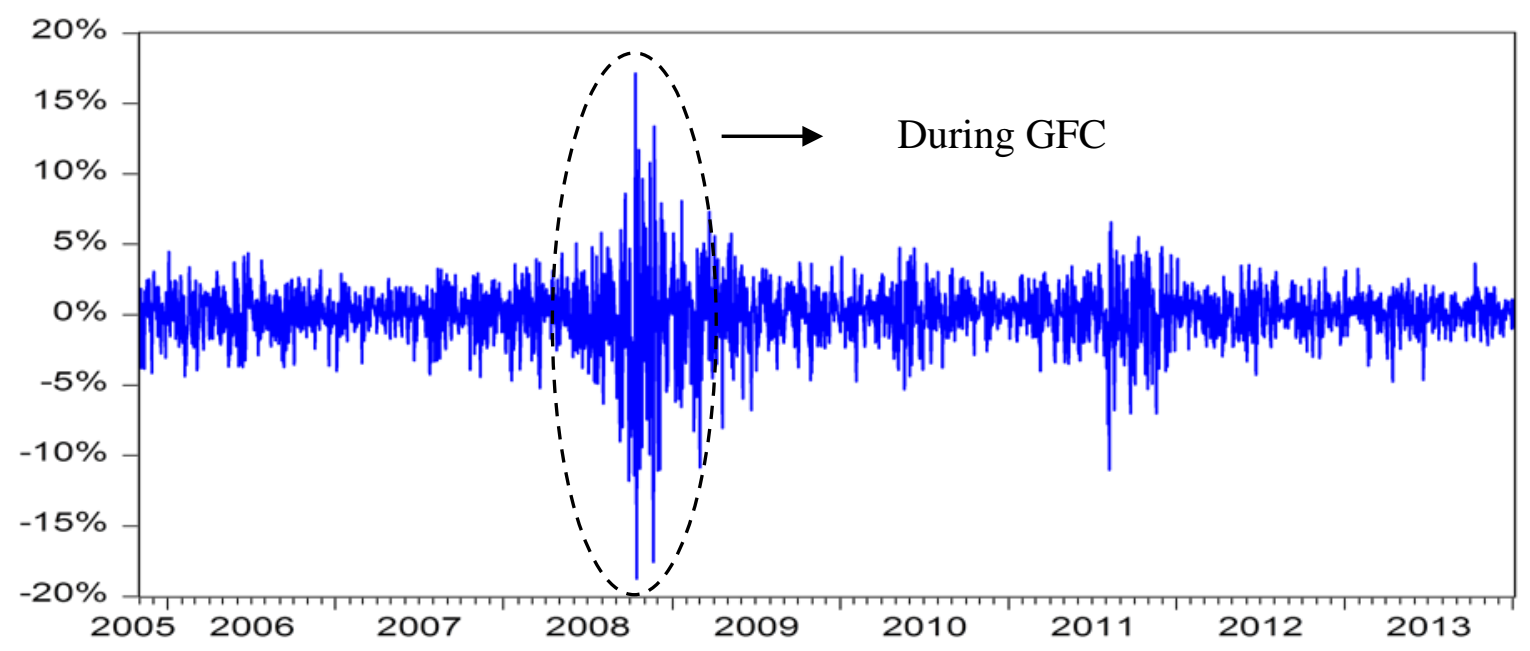

Figure 6. XLE flows (2005/11/01 - 2014/01/03)

(unit: 1000 shares)

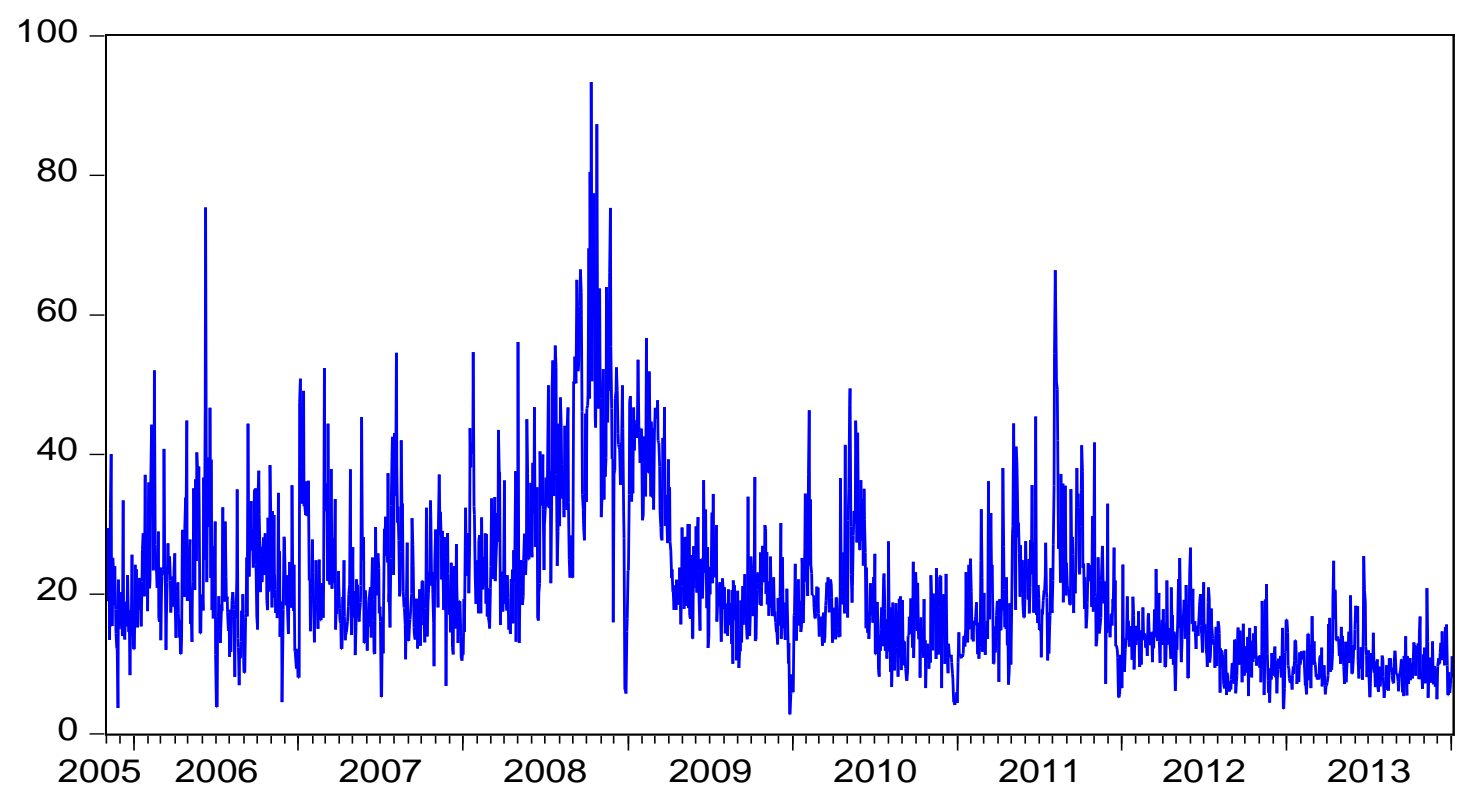


Figure 7. IYE flows (2005/11/01 - 2014/01/03)

(unit: 1000 shares)

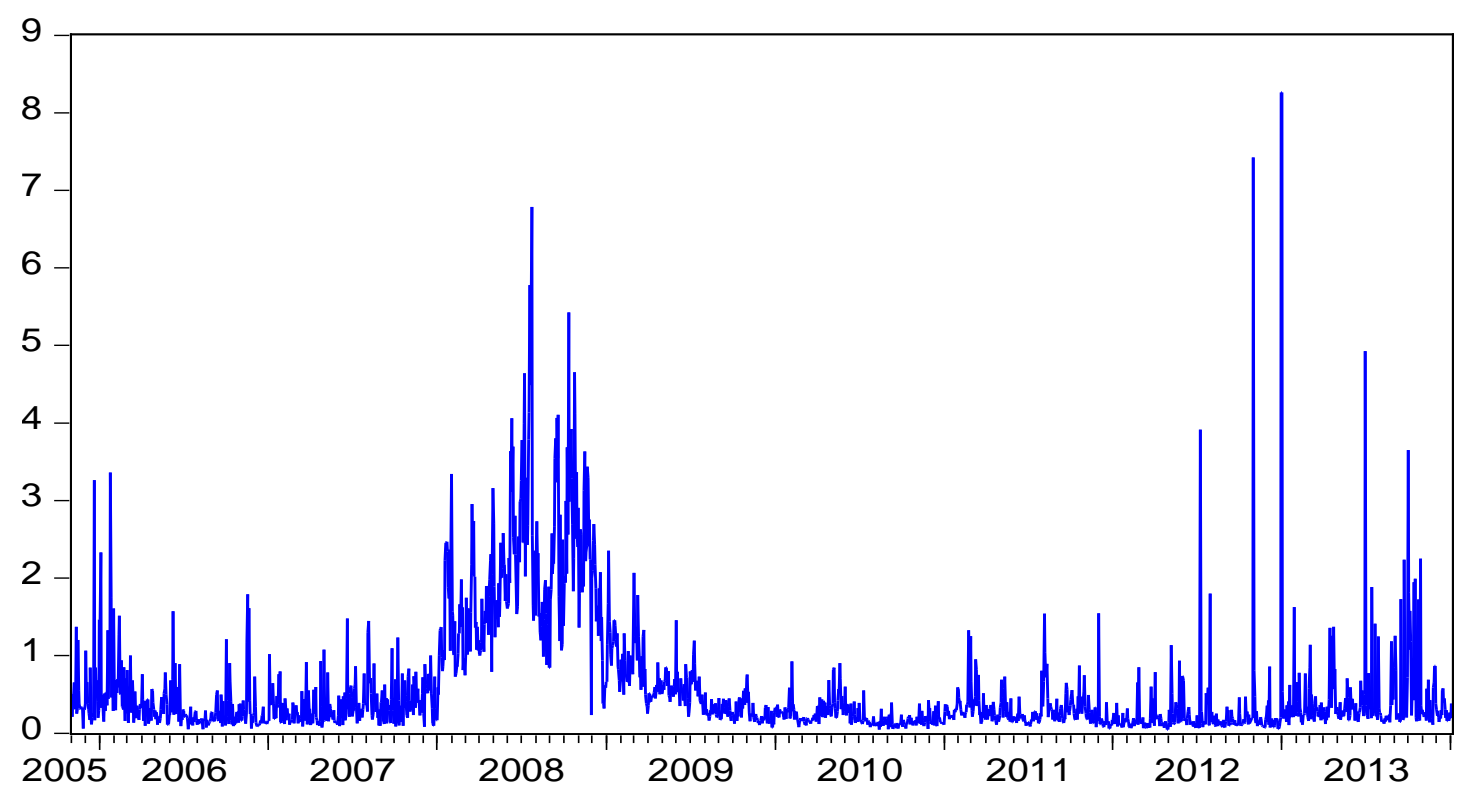

Figure 8. IXE flows (2005/11/01 - 2014/01/03)

(unit: 1000 shares)

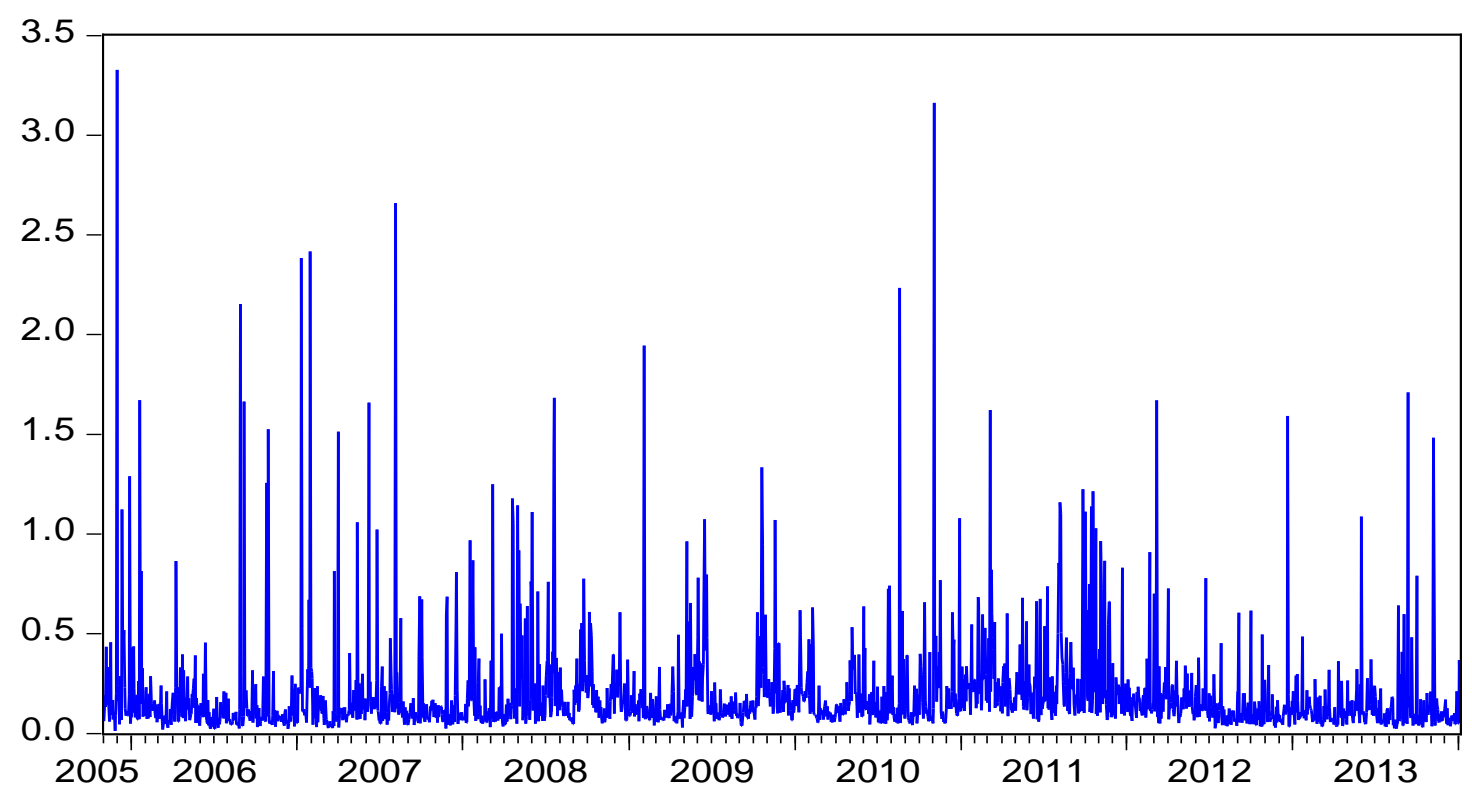


Figure 9. VDE flows (2005/11/01 - 2014/01/03)

(unit: 1000 shares)

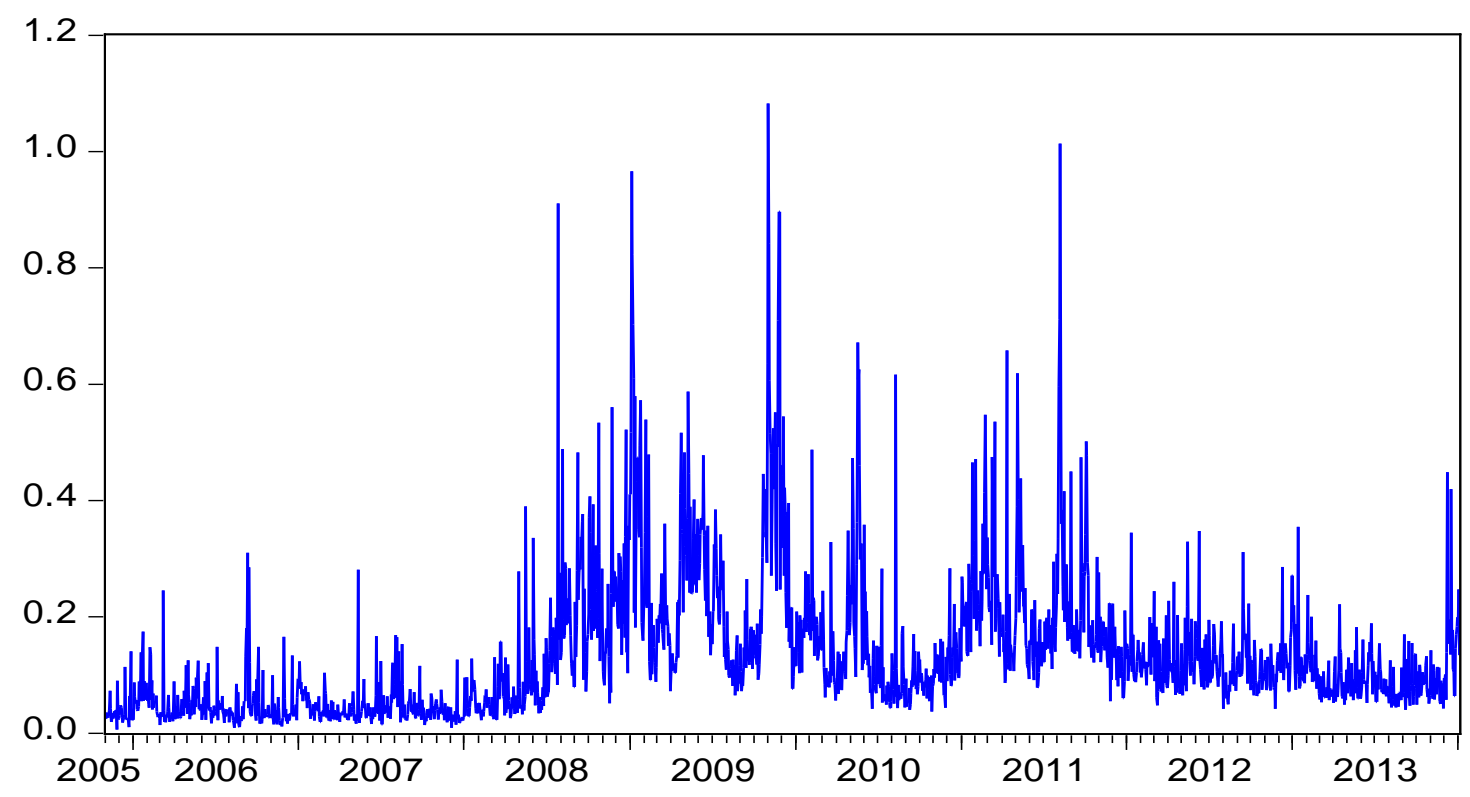

Figure 10. PXE flows (2005/11/01 - 2014/01/03)

(unit: 1000 shares)

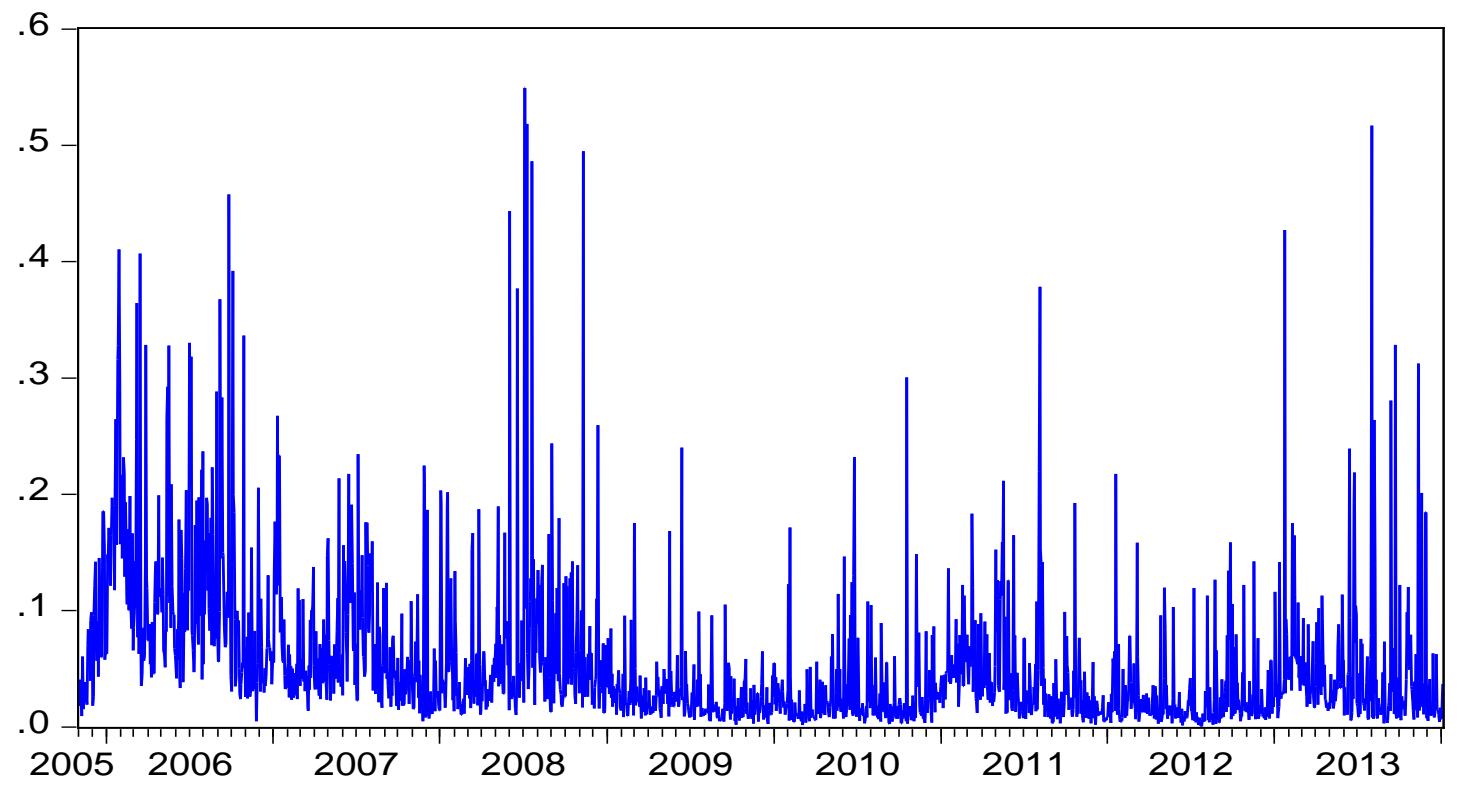

